\title{
Prioritization of Sub-Watersheds in a Large Semi-Arid Drainage Basin (Southern Jordan) Using Morphometric Analysis, GIS, and Multivariate Statistics
}

\section{Yahya Farhan 1*, Ali Anbar², Nisreen Al-Shaikh², Haifa Almohammad ${ }^{3}$, Sireen Alshawamreh², Manal Barghouthi²}

${ }^{1}$ Member of Trustee Council in Al-Ahliyya Amman University, Amman, Jordan

${ }^{2}$ Department of Geography, University of Jordan, Amman, Jordan

${ }^{3}$ Sustainability Land Management Member, Amman, Jordan

Email: *wjetfan47962@gmail.com

How to cite this paper: Farhan, Y., Anbar, A., Al-Shaikh, N., Almohammad, H., Alshawamreh, S. and Barghouthi, M. (2018) Prioritization of Sub-Watersheds in a Large Semi-Arid Drainage Basin (Southern Jordan) Using Morphometric Analysis, GIS, and Multivariate Statistics. Agricultural Sciences, 9, 437-468.

https://doi.org/10.4236/as.2018.94031

Received: March 16, 2018

Accepted: April 27, 2018

Published: April 30, 2018

Copyright $\odot 2018$ by authors and Scientific Research Publishing Inc. This work is licensed under the Creative Commons Attribution International License (CC BY 4.0).

http://creativecommons.org/licenses/by/4.0/

\begin{abstract}
GIS-based morphometric analysis was employed to prioritize the $\mathrm{W}$. $\mathrm{Mu}$ jib-Wala watershed southern Jordan. Seventy six fourth-order sub-watersheds were prioritized using morphometric analysis of ten linear and shape parameters. Each sub-watershed is prioritized by designated ranks based on the calculated compound parameter (Cp). The total score for each sub-basin is assigned as per erosion threat. The 76 sub-basins were grouped into four categories of priority: very high (12 sub-basins, $15.8 \%$ of the total), high (32 sub-watersheds, $42.1 \%$ of the total), moderate (25 sub-watersheds, $32.9 \%$ of the total), and low (7 sub-watersheds, $9.2 \%$ of the total). Sub-watersheds categorized as very high and high are subjected to high erosion risk, thus creating an urgent need for applying soil and water conservation measures. The relative diversity in land use practices and land cover, including variation in slope and soil types, are considered in proposing suitable conservation structures for sub-watersheds connected to each priority class. The adaptation of soil conservation measures priority-wise will reduce the erosivity effect on soil loss; while increasing infiltration rates; and water availability in soil profile. Principal component analysis (PCA) reduces the basic parameters and erosion risk parameters to three components, explaining $88 \%$ of the variance. The relationships of these components to the basic and erosion risk parameters were evaluated, and then the degree of inter-correlation among the morphometric parameters was explored. The verification of priority classes obtained through morphometric analysis was tested using Discriminant Analysis (DA). The re-
\end{abstract}


sults show a complete separation existing between the identified priority classes. Thus, soil erosion risk and geomorphic conditions are found entirely different from one class to another. The present results are intended to help decision makers to plan for efficient soil and water conservation measures to achieve future agricultural sustainability in the rainfed highlands of Jordan.

\section{Keywords}

Prioritization, Morphometric Analysis, GIS, Discriminant Analysis, Principal Component Analysis

\section{Introduction}

Rapid population growth $\approx 3 \%$ annually), and the persistent need for food production during the 1960s and '70s, caused continuous expansion of rainfed cultivation on marginal areas (average annual rainfall $<250 \mathrm{~mm}$ ), forest and rangeland, which in turn increased the pressure on soil and water resources. The destruction of vegetation cover historically and land use abuse, coupled with the absence of efficient conservation measures, and compounded by improper farming practices accelerates soil erosion. The impact of land use/cover changes on soil erosion risk in northern Jordan was assessed [1] [2]. Cultivated land with poor conservation measures exhibit a higher rate of soil erosion and decline in soil fertility. The only conservation practice dominant is inefficient old stone terracing where rainfed "mixed farming" is practiced [3]. Further, soil erosion is becoming more serious on moderate and steep slopes which were transformed into cultivated land. Repetitive heavy rainstorms are the major significant triggering factor for extreme soil erosion, landslide activity, and floods. Severe storms with maximum daily intensity in the range of $2.1-6.66 \mathrm{~mm} \cdot \mathrm{h}^{-1}$ are common in the highlands region [4] [5] [6]. Several case studies were carried out on watersheds prioritization in Jordan using morphometric analysis method, multivariate statistics, soil erosion susceptibility, and RUSLE soil loss modeling. For example, fourteen mini-watersheds of W. Shueib (Central Jordan) were prioritized for soil and water conservation [7] based on the method of morphometric analysis [8] [9] [10], and soil erosion susceptibility analysis [11] using GIS. Degradation of vegetation covers including forest, and the existence of W. Shueib structure along the eastern part of the catchment, caused serious soil erosion and landslides activity. Therefore, flooding and sediment discharge into the W. Shueib reservoir have increased during heavy rainstorms. Eleven mini-watersheds ( $78.6 \%$ of the total) are classified in the categories of moderate, high, and very high priority. Thus, they should be considered as potential areas for preferential conservation intervention, and must be prioritized immediately for soil and water conservation practices. Moreover, prioritization was performed for thirty one third-order mini-watersheds connected to W. Kerak (Southern Jordan) using morphometric analysis and RUSLE soil loss modeling 
methods, and GIS techniques [12]. Based on morphometric parameters and soil loss values, and their ranking scores, five priority classes were recognized: extremely high, very high, high, moderate and low priority. Fifteen mini-watersheds ( $48.4 \%$ of the total) are classified as extremely high, very high, and high priority. Therefore, these mini-watersheds must be given the highest priority for soil and water conservation to ensure future sustainable agriculture. Remote sensing and GIS techniques were adopted for prioritization of the Zarqa River catchment. Forty three fourth-order sub-basins were prioritized based on morphometric and Principal Component Analysis (PCA) [13]. The optimal priority classes were recognized and the effectiveness of erosion risk parameters in watershed prioritization was assessed. Prioritization of the 43 sub-basins was conducted using ten linear and shape parameters, and three parameters which are found to be of high correlation with components 1 and 2. Then different sub-basins were prioritized by ascribing ranks based on the calculated compound parameter $\left(C_{p}\right)$ using the two approaches. Comparison of the results indicated that prioritization of sub-basins based on morphometric analysis is more consistent and serves for better decision making in conservation planning as compared with the PCA approach. Seventeen sub-basins (39.5\% of the total) grouped under the high priority class, and are subjected to high erosion risk. Nineteen sub-basins (44.2\% of the total) are classified as moderate priority for soil conservation. The transformation of enormous areas of forest and rangeland into farming practices and the expansion of rainfed "mixed farming" (mainly cereals) accelerates soil erosion. Soil erosion eventually induced low agricultural productivity, changes in river morphology, high sediment yield and reduction in reservoir storage capacity. The future life of constructed and proposed dams in Jordan, i.e., W. Alarab [14]; King Talal Reservoir [15]; W .Mujib dam [16], and W. Wala dam [17] are seriously threatened by the inflow of high sediment loads. Soil erosion loss for the catchments draining to the rift was found to be 1.328 million tons year ${ }^{-1}$, which means, $0.14 \mathrm{~cm}$ of the top soil is eroded annually [18]. It is obvious that the recorded soil erosion rates in different parts of the highlands in Jordan are greater than the accepted soil loss tolerance limits for the Mediterranean environment which were estimated at from 2 to 12 ton $\cdot$ ha $^{-1} \cdot$ year $^{-1}$ [19] [20].

Prioritization of sub-watersheds refers to the "ranking of different sub-watersheds as the order they have to be selected for appropriate soil conservation measures adaptation" [21]. Erosion risk parameters must be calculated to prioritize sub-watersheds for soil conservation. The linear parameters possess a direct relationship with erodibility. Therefore, the highest value of the linear variables was ranked 1, the second highest value ranked 2 and so on, and the least value was rated last in rank. Furthermore, the shape parameters possess an inverse relation with erodibility, thus, the lower their values, the greater the erodibility [22]. Consequently, the lowest value of shape parameter was rated as rank 1 and the second lowest as rank 2 and so on, and the highest value was rated last in rank [23]. The Compound Parameter $\left(C_{p}\right)$ was computed by adding up all the 
ranks of linear parameters, as well as shape parameters, and then, dividing by the number of all parameters. Following the rating of every single morphometric parameter, the ranking values for all linear and shape parameters referring to each sub-watershed are added up for each of the sub-watersheds to achieve a compound parameter $(\mathrm{Cp})$ score based on the average value of these parameters. Further, the sub-watersheds having the lowest compound parameter score was designated the highest priority, the next higher value was assigned as second priority and so on [21]. Highest priority indicates the greater degree of soil erosion in that particular sub-basin, thus, it is considered a potential area for applying soil conservation measures [24].

Several methods have been developed and elaborated for watersheds prioritization. Eleven of the twenty five studies ( $44 \%$ of the total) employed morphometric analysis method in prioritization [8] [10] [13] [21] [25] [26] [27]. Whereas the other 14 studies (56\% of the total) adopted the morphometric analysis method combined with one or two of the following methods, such as: sediment yield index method(SYI) [8] [22]; sediment production rate (SPR) method [28]; USLE/RUSLE models for estimating soil loss [7] [29] [30]; soil erosion susceptibility analysis [12]; runoff potential method [31]; land use/cover analysis [32] [33]; sediment yield index(SYI)and land use/cover [23]; weighted sum analysis technique [34]; fuzzy analytical hierarchy process [30] [35]; Snyder's method of unit hydrograph, and land use/cover [36].

In the current study, the authors employed the morphometric analysis method to:

1) Prioritize 76 fourth-order sub-watersheds for soil and water conservation based on the morphometric analysis method using GIS and RS.

2) Generate a spatial map illustrating the distribution of final priority classes representing the 76 sub-watersheds,

3) Explore the relationship of major components determined based on PCA to erosion risk parameters and the basic morphometric parameters.

4) Test the validity of the achieved priority classes by means of Discriminant Analysis, and to determine the nature of Discriminant functions in relation to the character of components,

5) Propose suitable soil and water conservation measures for the $\mathrm{W} . \mathrm{Mu}$ jib-Wala catchment.

Information on soil type, slope categories, and current land use/cover has been provided in order to help in suggesting appropriate soil conservation measures for sub-watersheds in each priority class. Prioritization in the present study demonstrates the role of powerful GIS, RS, and the morphometric analysis method in ranking different sub-watersheds in relation to the order in which they have to be taken for conservation measures [24]. Further, quantitative morphometric analysis of drainage networks is considered the key approach for understanding the hydro-morphological processes acting over drainage basins. Erosion risk parameters can be measured and calculated using DEM's and Arc GIS software. Morphometric analysis of linear and shape parameters are the 
common approach developed and adopted to compute the compound parameter (Cp) on which prioritization of sub-watersheds is perceived [8] [10] [22] [32]. It has been argued in the recent past that erosion risk morphometric parameters are the most valid and consistent parameters in relation to erodibility and sub-watershed prioritization for conservation practice as compared to other methods of prioritization [13].

\section{Study Area}

W. Mujib-Wala catchment represents the second largest watershed draining to the Rift, and discharging directly into the Dead Sea. The catchment is located between $30^{\circ} 39^{\prime}$ to $31^{\circ}$ to $41^{\prime} \mathrm{N}$ latitude, and $35^{\circ} 30^{\prime}$ to $36^{\circ} 30^{\prime}$ East longitude (Figure 1). The watershed attains a maximum elevation of $1277 \mathrm{~m}$ (a.s.l) and a minimum of - $431 \mathrm{~m}$ (b.s.l) at the outlet of the wadi. The catchment has been subjected to progressive stages of rejuvenation due to continuous base-level changes along the Dead Sea, the lowest base level in the Jordan Rift [37] [38]. Thus, deeply dissected topography, incised drainage, and over-steepened and interrupted slopes are characteristic. Moreover, the catchment suffers from serious geo-hazards such as landslides activity, high sediment yield, severe soil erosion, and repetitive flooding [13]. Slope categories range from $0^{\circ}-10^{\circ}$ in the east, to nearly vertical slopes bordering the canyons in the western part of the watershed, and the faulted-erosional escarpment overlooking the Dead Sea. Therefore, slope gradients have a direct impact on surface runoff and geomorphic processes over the demarcated sub-basins.

High hypsometric integral (HI) values ranging from $0.70 \%$ to $0.89 \%$ predominate in the watershed, indicating that the W. Mujib-Wala and the 76 sub-watersheds are at the youth-age stage of geomorphic development. Consequently, the sub-watersheds evince high soil erosion rates [3], high sediment yield production [16] [17], high possibility of flooding and landslide activity especially in the western part of the watershed [39]. Mean annual rainfall ranges from $346 \mathrm{~mm}$ at Madaba area, the north-western edge of the catchment, $164 \mathrm{~mm}$ at the W. Mujib weather station, to $331 \mathrm{~mm}$ and $335 \mathrm{~mm}$ at Qasr and Rabba town' respectively. Daily temperatures range from a maximum of $>40^{\circ} \mathrm{C}$ in $\mathrm{Au}$ gust (close to the Dead Sea), to a minimum of $-5^{\circ} \mathrm{C}$ in January close to Mazar town. Several rock units are exposed in the catchment, ranging from Cambrian sandstones to Quaternary fluvial terraces and lacustrine deposits. Rainfed cultivation is practiced on the summit surfaces and undulating terrain units receiving 250 - $350 \mathrm{~mm}$ of rainfall annually (Madaba, Qasr, and Rabba areas). Whereas irrigated farming from springs, Al-Haidan groundwater wells, and base flow dominated the lowlands (i.e., wadi floor terraces and flood plains) below W. Mujib and W. Wala dams. Scattered irrigated farming based on groundwater wells is characteristic of the eastern W. Mujib-Wala catchment. However, hydrological prospecting and water resources assessment are in progress at 

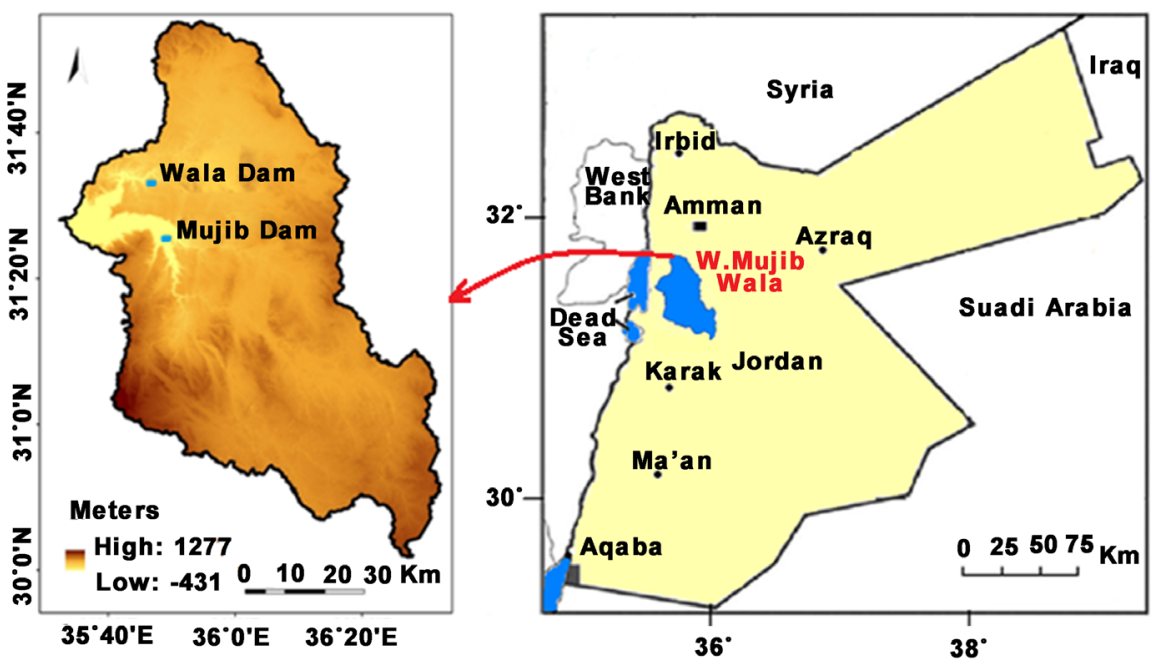

Figure 1. Study area.

present. The most promising sites for groundwater exploration in W. Wala were demarcated [40]. Agricultural land utilization occupies 7\% of the total catchment. The western part of the catchment comprises a major component of the W. Mujib Natural Reserve. Palm trees, tamarisk trees, and oleander shrubs are observed in wadi beds.

\section{Materials and Methods}

\subsection{Derivation of Erosion Risk Parameters}

The morphometric analysis method was employed to conduct prioritization for the 76 sub-watersheds. Five linear morphometric parameters $\left(R_{b}, D_{d}, F_{s}, T_{r}\right.$, and $\left.L_{o}\right)$ and five shape morphometric parameters $\left(R_{f} B_{s}, R_{e}, C_{\mathcal{c}}\right.$ and $\left.R_{e}\right)$ (see Table 1) were calculated as a first step to compute the compound parameter $(\mathrm{Cp})$ in order to categorize the sub-watersheds into priority classes. The linear parameters comprise the bifurcation ratio, drainage density, stream frequency, texture ratio, and length of overland flow.

The bifurcation ratio $\left(R_{b}\right)$ refers to the ratio of the number of streams in lower order $\left(N_{u}\right)$ to the number of the streams of the next higher order $\left(N_{u}+1\right)$, and it computed as:

$$
R_{b}=N_{u} / N_{u}+1 \text {, where }
$$

$N_{u}=$ total number of stream segments of order - $u-$

$N_{u}+1=$ no. of segments of the next higher order [41] [42].

High $R_{b}$ values indicate high overland flow and early hydrograph peak with a high potential of possibility for flash flooding associated with severe rainstorms [43], thus increasing soil erosion rates and sediment discharge in the main channel.

Drainage density $\left(D_{d}\right)$ is introduced by Horton [41] as a significant indicator of the linear scale of landform elements in fluvially eroded topography. $D_{d}$ is defined as the total length of streams in a drainage basin per unit area, or 
Table 1. Morphometric characteristics of the 76 sub-watersheds

\begin{tabular}{|c|c|c|c|c|c|c|c|c|c|c|c|c|c|c|c|}
\hline \multirow{2}{*}{$\begin{array}{l}\text { Sub-watersh } \\
\text { ed no. }\end{array}$} & \multicolumn{5}{|c|}{ Basic Parameters } & \multicolumn{5}{|c|}{ Linear Parameters } & \multicolumn{5}{|c|}{ Shape Parameters } \\
\hline & $A$ & $P$ & $\boldsymbol{N}_{U}$ & $L_{b}$ & $L_{u}$ & $\boldsymbol{R}_{b}$ & $D_{d}$ & $F_{s}$ & $T_{r}$ & $L_{o}$ & $\boldsymbol{R}_{f}$ & $B_{s}$ & $\boldsymbol{R}_{e}$ & $C_{c}$ & $\boldsymbol{R}_{c}$ \\
\hline 1 & 54.09 & 47.68 & 60 & 13.12 & 67.00 & 3.64 & 1.24 & 1.11 & 1.26 & 0.62 & 0.31 & 3.18 & 0.63 & 3.66 & 0.30 \\
\hline 2 & 103.04 & 93.13 & 112 & 21.47 & 128.94 & 4.50 & 1.25 & 1.09 & 1.20 & 0.63 & 0.22 & 4.47 & 0.53 & 5.18 & 0.15 \\
\hline 3 & 86.63 & 60.83 & 93 & 13.16 & 123.80 & 4.26 & 1.43 & 1.07 & 1.53 & 0.71 & 0.50 & 2.00 & 0.80 & 3.69 & 0.29 \\
\hline 4 & 98.75 & 90.93 & 108 & 23.00 & 131.06 & 4.64 & 1.33 & 1.09 & 1.19 & 0.66 & 0.19 & 5.36 & 0.49 & 5.16 & 0.15 \\
\hline 5 & 130.19 & 81.25 & 160 & 16.93 & 184.59 & 5.12 & 1.42 & 1.23 & 1.97 & 0.71 & 0.45 & 2.20 & 0.76 & 4.02 & 0.25 \\
\hline 6 & 19.76 & 24.82 & 35 & 7.30 & 30.34 & 3.11 & 1.54 & 1.77 & 1.41 & 0.77 & 0.37 & 2.70 & 0.69 & 3.15 & 0.40 \\
\hline 7 & 50.75 & 43.83 & 54 & 12.79 & 69.04 & 3.52 & 1.36 & 1.06 & 1.23 & 0.68 & 0.31 & 3.22 & 0.63 & 3.47 & 0.33 \\
\hline 8 & 57.61 & 45.54 & 78 & 13.84 & 86.34 & 3.96 & 1.50 & 1.35 & 1.71 & 0.75 & 0.30 & 3.32 & 0.62 & 3.38 & 0.35 \\
\hline 9 & 53.69 & 51.83 & 58 & 12.02 & 72.80 & 3.87 & 1.36 & 1.08 & 1.12 & 0.68 & 0.37 & 2.69 & 0.69 & 3.99 & 0.25 \\
\hline 10 & 18.00 & 22.70 & 28 & 7.43 & 31.87 & 2.69 & 1.77 & 1.56 & 1.23 & 0.89 & 0.33 & 3.07 & 0.64 & 3.02 & 0.44 \\
\hline 11 & 24.71 & 33.96 & 34 & 10.03 & 39.08 & 3.00 & 1.58 & 1.38 & 1.00 & 0.79 & 0.25 & 4.07 & 0.56 & 3.85 & 0.27 \\
\hline 12 & 184.99 & 135.61 & 238 & 24.80 & 265.13 & 5.83 & 1.43 & 1.29 & 1.76 & 0.72 & 0.30 & 3.32 & 0.62 & 5.63 & 0.13 \\
\hline 13 & 125.86 & 153.58 & 150 & 38.19 & 170.39 & 5.02 & 1.35 & 1.19 & 0.98 & 0.68 & 0.09 & 11.59 & 0.33 & 7.72 & 0.07 \\
\hline 14 & 37.02 & 43.99 & 51 & 9.26 & 51.74 & 3.60 & 1.40 & 1.38 & 1.16 & 0.70 & 0.43 & 2.32 & 0.74 & 4.08 & 0.24 \\
\hline 15 & 48.56 & 55.58 & 70 & 16.54 & 64.84 & 4.26 & 1.34 & 1.44 & 1.26 & 0.67 & 0.18 & 5.63 & 0.48 & 4.50 & 0.20 \\
\hline 16 & 29.33 & 28.19 & 38 & 6.02 & 40.23 & 3.13 & 1.37 & 1.30 & 1.35 & 0.69 & 0.81 & 1.24 & 1.01 & 2.94 & 0.46 \\
\hline 17 & 87.16 & 81.60 & 99 & 18.79 & 112.19 & 4.42 & 1.29 & 1.14 & 1.21 & 0.64 & 0.25 & 4.05 & 0.56 & 4.93 & 0.16 \\
\hline 18 & 28.98 & 36.98 & 34 & 10.67 & 37.38 & 3.23 & 1.29 & 1.17 & 0.92 & 0.65 & 0.25 & 3.93 & 0.57 & 3.88 & 0.27 \\
\hline 19 & 118.55 & 102.06 & 139 & 25.02 & 175.88 & 4.82 & 1.48 & 1.17 & 1.36 & 0.74 & 0.19 & 5.28 & 0.49 & 5.29 & 0.14 \\
\hline 20 & 89.67 & 80.15 & 99 & 17.03 & 129.87 & 4.44 & 1.45 & 1.10 & 1.24 & 0.72 & 0.31 & 3.24 & 0.63 & 4.78 & 0.18 \\
\hline 21 & 21.35 & 35.73 & 34 & 7.48 & 29.79 & 3.06 & 1.40 & 1.59 & 0.95 & 0.70 & 0.38 & 2.62 & 0.70 & 4.36 & 0.21 \\
\hline 22 & 18.84 & 22.79 & 27 & 7.15 & 24.18 & 3.00 & 1.28 & 1.43 & 1.18 & 0.64 & 0.37 & 2.71 & 0.69 & 2.96 & 0.46 \\
\hline 23 & 12.12 & 17.59 & 17 & 5.42 & 14.40 & 2.17 & 1.19 & 1.40 & 0.97 & 0.59 & 0.41 & 2.43 & 0.72 & 2.85 & 0.49 \\
\hline 24 & 43.78 & 43.89 & 55 & 9.39 & 60.05 & 3.73 & 1.37 & 1.26 & 1.25 & 0.69 & 0.50 & 2.01 & 0.79 & 3.74 & 0.29 \\
\hline 25 & 22.88 & 25.26 & 33 & 6.37 & 34.06 & 2.93 & 1.49 & 1.44 & 1.31 & 0.74 & 0.56 & 1.77 & 0.85 & 2.98 & 0.45 \\
\hline 26 & 37.63 & 49.06 & 52 & 12.35 & 53.11 & 3.71 & 1.41 & 1.38 & 1.06 & 0.71 & 0.25 & 4.05 & 0.56 & 4.51 & 0.20 \\
\hline 27 & 84.92 & 65.75 & 103 & 13.60 & 112.02 & 4.49 & 1.32 & 1.21 & 1.57 & 0.66 & 0.46 & 2.18 & 0.76 & 4.03 & 0.25 \\
\hline 28 & 115.78 & 112.66 & 137 & 24.18 & 157.41 & 4.81 & 1.36 & 1.18 & 1.22 & 0.68 & 0.20 & 5.05 & 0.50 & 5.91 & 0.11 \\
\hline 29 & 70.13 & 68.15 & 88 & 15.20 & 103.93 & 4.22 & 1.48 & 1.25 & 1.29 & 0.74 & 0.30 & 3.30 & 0.62 & 4.59 & 0.19 \\
\hline 30 & 55.89 & 54.03 & 69 & 14.94 & 72.16 & 3.78 & 1.29 & 1.23 & 1.28 & 0.65 & 0.25 & 4.00 & 0.56 & 4.08 & 0.24 \\
\hline 31 & 25.66 & 33.23 & 30 & 8.24 & 33.27 & 2.97 & 1.30 & 1.17 & 0.90 & 0.65 & 0.38 & 2.65 & 0.69 & 3.70 & 0.29 \\
\hline 32 & 27.17 & 32.46 & 36 & 7.03 & 43.16 & 3.17 & 1.59 & 1.33 & 1.11 & 0.79 & 0.55 & 1.82 & 0.84 & 3.51 & 0.32 \\
\hline 33 & 32.14 & 30.22 & 35 & 8.61 & 43.23 & 11.33 & 1.35 & 1.09 & 1.16 & 0.67 & 0.43 & 2.31 & 0.74 & 3.01 & 0.44 \\
\hline 34 & 38.03 & 41.10 & 46 & 10.84 & 54.73 & 3.43 & 1.44 & 1.21 & 1.12 & 0.72 & 0.32 & 3.09 & 0.64 & 3.76 & 0.28 \\
\hline 35 & 20.30 & 18.38 & 28 & 7.27 & 31.18 & 2.72 & 1.54 & 1.38 & 1.52 & 0.77 & 0.38 & 2.60 & 0.70 & 2.30 & 0.75 \\
\hline
\end{tabular}


Continued

\begin{tabular}{|c|c|c|c|c|c|c|c|c|c|c|c|c|c|c|c|}
\hline 36 & 59.51 & 55.60 & 64 & 15.56 & 84.22 & 4.03 & 1.42 & 1.08 & 1.15 & 0.71 & 0.25 & 4.07 & 0.56 & 4.07 & 0.24 \\
\hline 37 & 22.61 & 33.02 & 35 & 8.39 & 32.62 & 3.02 & 1.44 & 1.55 & 1.06 & 0.72 & 0.32 & 3.11 & 0.64 & 3.92 & 0.26 \\
\hline 38 & 30.40 & 37.64 & 44 & 8.39 & 43.36 & 3.38 & 1.43 & 1.45 & 1.17 & 0.71 & 0.43 & 2.31 & 0.74 & 3.85 & 0.27 \\
\hline 39 & 25.08 & 35.64 & 28 & 10.75 & 33.35 & 2.83 & 1.33 & 1.12 & 0.79 & 0.66 & 0.22 & 4.61 & 0.53 & 4.02 & 0.25 \\
\hline 40 & 66.82 & 66.25 & 76 & 15.87 & 96.63 & 3.94 & 1.45 & 1.14 & 1.15 & 0.72 & 0.27 & 3.77 & 0.58 & 4.57 & 0.19 \\
\hline 41 & 52.66 & 58.55 & 68 & 12.63 & 79.15 & 3.83 & 1.50 & 1.29 & 1.16 & 0.75 & 0.33 & 3.03 & 0.65 & 4.55 & 0.19 \\
\hline 42 & 32.04 & 39.20 & 45 & 9.22 & 44.93 & 3.40 & 1.40 & 1.40 & 1.15 & 0.70 & 0.38 & 2.65 & 0.69 & 3.91 & 0.26 \\
\hline 43 & 22.59 & 27.46 & 30 & 7.17 & 30.20 & 2.68 & 1.34 & 1.33 & 1.09 & 0.67 & 0.44 & 2.27 & 0.75 & 3.26 & 0.38 \\
\hline 44 & 75.23 & 73.37 & 85 & 10.48 & 100.55 & 4.03 & 1.34 & 1.13 & 1.16 & 0.67 & 0.68 & 1.46 & 0.93 & 4.77 & 0.18 \\
\hline 45 & 38.65 & 40.07 & 44 & 13.82 & 53.28 & 3.45 & 1.38 & 1.14 & 1.10 & 0.69 & 0.20 & 4.94 & 0.51 & 3.64 & 0.30 \\
\hline 46 & 50.64 & 52.94 & 51 & 14.93 & 65.29 & 4.37 & 1.29 & 1.01 & 0.96 & 0.64 & 0.23 & 4.40 & 0.54 & 4.20 & 0.23 \\
\hline 47 & 18.38 & 28.21 & 30 & 5.15 & 29.40 & 2.97 & 1.60 & 1.63 & 1.06 & 0.80 & 0.69 & 1.44 & 0.94 & 3.71 & 0.29 \\
\hline 48 & 55.73 & 50.49 & 70 & 13.36 & 74.23 & 3.98 & 1.33 & 1.26 & 1.39 & 0.67 & 0.31 & 3.20 & 0.63 & 3.82 & 0.27 \\
\hline 49 & 63.52 & 49.05 & 75 & 14.42 & 86.67 & 3.79 & 1.36 & 1.18 & 1.53 & 0.68 & 0.31 & 3.27 & 0.62 & 3.47 & 0.33 \\
\hline 50 & 43.55 & 46.10 & 45 & 10.65 & 58.20 & 3.42 & 1.34 & 1.03 & 0.98 & 0.67 & 0.38 & 2.60 & 0.70 & 3.94 & 0.26 \\
\hline 51 & 34.45 & 40.02 & 37 & 12.44 & 50.22 & 3.12 & 1.46 & 1.07 & 0.92 & 0.73 & 0.22 & 4.49 & 0.53 & 3.85 & 0.27 \\
\hline 52 & 64.03 & 58.99 & 85 & 14.28 & 90.98 & 4.00 & 1.42 & 1.33 & 1.44 & 0.71 & 0.31 & 3.18 & 0.63 & 4.16 & 0.23 \\
\hline 53 & 75.94 & 81.54 & 102 & 16.49 & 107.70 & 4.27 & 1.42 & 1.34 & 1.25 & 0.71 & 0.28 & 3.58 & 0.60 & 5.28 & 0.14 \\
\hline 54 & 27.94 & 22.11 & 43 & 6.12 & 43.57 & 3.40 & 1.56 & 1.54 & 1.94 & 0.78 & 0.75 & 1.34 & 0.97 & 2.36 & 0.72 \\
\hline 55 & 92.86 & 108.14 & 123 & 25.58 & 131.41 & 4.56 & 1.42 & 1.32 & 1.14 & 0.71 & 0.14 & 7.05 & 0.42 & 6.33 & 0.10 \\
\hline 56 & 23.03 & 24.36 & 30 & 9.85 & 32.12 & 3.25 & 1.39 & 1.30 & 1.23 & 0.70 & 0.24 & 4.21 & 0.55 & 2.86 & 0.49 \\
\hline 57 & 42.10 & 47.26 & 50 & 10.79 & 55.85 & 3.57 & 1.33 & 1.19 & 1.06 & 0.66 & 0.36 & 2.77 & 0.68 & 4.11 & 0.24 \\
\hline 58 & 119.35 & 89.11 & 152 & 23.41 & 164.30 & 4.97 & 1.38 & 1.27 & 1.71 & 0.69 & 0.22 & 4.59 & 0.53 & 4.60 & 0.19 \\
\hline 59 & 32.38 & 39.36 & 41 & 11.05 & 47.15 & 3.31 & 1.46 & 1.27 & 1.04 & 0.73 & 0.26 & 3.77 & 0.58 & 3.90 & 0.26 \\
\hline 60 & 36.85 & 41.16 & 49 & 11.61 & 58.85 & 3.33 & 1.60 & 1.33 & 1.19 & 0.80 & 0.27 & 3.66 & 0.59 & 3.83 & 0.27 \\
\hline 61 & 115.97 & 84.45 & 34 & 23.43 & 177.69 & 5.11 & 1.53 & 0.29 & 0.40 & 0.77 & 0.21 & 4.73 & 0.52 & 4.42 & 0.20 \\
\hline 62 & 39.29 & 39.40 & 50 & 9.95 & 57.36 & 3.63 & 1.46 & 1.27 & 1.27 & 0.73 & 0.40 & 2.52 & 0.71 & 3.55 & 0.32 \\
\hline 63 & 27.70 & 37.42 & 40 & 9.39 & 41.41 & 3.21 & 1.49 & 1.44 & 1.07 & 0.75 & 0.31 & 3.18 & 0.63 & 4.01 & 0.25 \\
\hline 64 & 56.28 & 47.85 & 75 & 12.92 & 83.47 & 3.91 & 1.48 & 1.33 & 1.57 & 0.74 & 0.34 & 2.96 & 0.66 & 3.60 & 0.31 \\
\hline 65 & 20.53 & 23.51 & 30 & 8.84 & 26.75 & 2.83 & 1.30 & 1.46 & 1.28 & 0.65 & 0.26 & 3.81 & 0.58 & 2.93 & 0.47 \\
\hline 66 & 27.38 & 33.73 & 39 & 8.95 & 40.74 & 3.17 & 1.49 & 1.42 & 1.16 & 0.74 & 0.34 & 2.92 & 0.66 & 3.64 & 0.30 \\
\hline 67 & 52.72 & 58.51 & 70 & 10.58 & 77.10 & 3.75 & 1.46 & 1.33 & 1.20 & 0.73 & 0.47 & 2.12 & 0.77 & 4.55 & 0.19 \\
\hline 68 & 52.89 & 58.06 & 62 & 10.82 & 73.28 & 3.95 & 1.39 & 1.17 & 1.07 & 0.69 & 0.45 & 2.21 & 0.76 & 4.50 & 0.20 \\
\hline 69 & 41.56 & 41.56 & 51 & 12.47 & 64.97 & 3.67 & 1.56 & 1.23 & 1.23 & 0.78 & 0.27 & 3.74 & 0.58 & 3.64 & 0.30 \\
\hline 70 & 30.55 & 37.24 & 34 & 11.41 & 42.36 & 2.98 & 1.39 & 1.11 & 0.91 & 0.69 & 0.23 & 4.26 & 0.55 & 3.80 & 0.28 \\
\hline 71 & 167.85 & 128.14 & 211 & 22.49 & 239.01 & 5.84 & 1.42 & 1.26 & 1.65 & 0.71 & 0.33 & 3.01 & 0.65 & 5.58 & 0.13 \\
\hline 72 & 15.48 & 19.25 & 23 & 7.06 & 23.34 & 2.67 & 1.51 & 1.49 & 1.19 & 0.75 & 0.31 & 3.22 & 0.63 & 2.76 & 0.52 \\
\hline
\end{tabular}




\begin{tabular}{|c|c|c|c|c|c|c|c|c|c|c|c|c|c|c|c|}
\hline 73 & 93.67 & 76.18 & 112 & 18.19 & 142.62 & 4.63 & 1.52 & 1.20 & 1.47 & 0.76 & 0.28 & 3.53 & 0.60 & 4.44 & 0.20 \\
\hline 74 & 30.90 & 40.49 & 45 & 11.28 & 44.95 & 3.26 & 1.45 & 1.46 & 1.11 & 0.73 & 0.24 & 4.11 & 0.56 & 4.11 & 0.24 \\
\hline 75 & 47.34 & 53.66 & 59 & 14.41 & 69.17 & 3.87 & 1.46 & 1.25 & 1.10 & 0.73 & 0.23 & 4.39 & 0.54 & 4.40 & 0.21 \\
\hline 76 & 68.20 & 61.56 & 90 & 14.44 & 95.18 & 4.24 & 1.40 & 1.32 & 1.46 & 0.70 & 0.33 & 3.06 & 0.65 & 4.21 & 0.23 \\
\hline
\end{tabular}

$$
D_{d}=L_{u} / A, \text { where }
$$

$A$ is the basin area

$L_{u}$ is the total stream length

Stream frequency $\left(F_{s}\right)$ is computed as the ratio of the total number of streams $\left(N_{u}\right)$ of all orders in a watershed to the catchment area $(A)$ [41]. It denotes the texture of the drainage network, and is expressed by the following equation:

$$
F_{s}=N_{u} / A \text {, where }
$$

$N_{u}$ is the total number of streams

$A$ is the area of a drainage basin

Texture ratio $\left(T_{r}\right)$ is defined as the ratio of the total number of streams of the first order $\left(N_{1}\right)$ to the perimeter of the drainage basin. Texture ratio is determined by:

$$
N_{u} / P \text { where }
$$

$N_{u}=$ the total number of streams of all orders

$P=$ perimeter $(\mathrm{km})$

Length of overland flow $\left(L_{o}\right)$ is the length of water over the ground before it gets concentrated into definite stream channels [41], and is determined by the equation:

$$
L_{o}=H / L_{b} \text {, where }
$$

$H=$ basin relief $\left(B_{h}\right) \mathrm{m}$

$L_{b}=$ basin length $(\mathrm{km})$

$L_{o}$ parameter is related inversely to the average slope of the channel and is equivalent to the length of sheet flow to a large extent [41].

The shape parameters comprise form factor, shape factor, elongation ratio, compactness coefficient, and circularity ratio.

Form factor $\left(\boldsymbol{R}_{\boldsymbol{f}}\right)$ refers to the ratio of the area of drainage basin $(A)$ to the square of the basin length $\left(L_{b}^{2}\right)$ [41] [42]. It is computed according to the following:

$$
R_{f}=A / L_{b}^{2} \quad \text { where }
$$

higher values of $R_{f}$ indicate a more circular shape of a catchment, whereas small $R_{f}$ values $(<0.45)$ imply that the basin is elongated [41]. A catchment characterized by high $R_{f}$ has high peak flows of shorter duration.

Shape factor $\left(B_{s}\right)$ refers to the ratio of the square of the basin length to the area of the basin, or 


$$
B_{s}=L_{b}^{2} / A
$$

Shape factor provides a notion towards the circular nature of the watershed. The greater the circular character, the greater is the fast response of the catchment following an intense rainstorm [44].

Elongation ratio $\left(R_{e}\right)$ is denoted by

$$
R_{e}=1.128 \sqrt{a / L b}
$$

Variations in geology and climate cause prominent variation in $R_{e}$ values. Low values of $R_{e}$ indicate that the watershed is more elongated. When $R_{e}$ values approach 1.0, the shape of the watershed becomes circular [45].

Compactness coefficient $\left(C_{c}\right)$ parameter is developed by Gravelius [46] as a shape measure of a watershed. $C_{c}$ is defined as the ratio of perimeter of a watershed to the circumference of the circle area, which is equal to the area of the watershed, or

$$
C_{c}=\frac{P}{2 \sqrt{\pi A}} \text { where }
$$

$P=$ perimeter of the basin $(\mathrm{km})$

$A=$ area of the basin $\left(\mathrm{km}^{2}\right)$

When the $C_{c}$ value is 1.0 , it denotes that the catchment is a perfect circle. If the value is 1.28 , the basin is more square-shaped, whereas the basin is considered a very elongated one, when the $C_{c}$ value $>3.0$ [47].

Circularity ratio $\left(\boldsymbol{R}_{c}\right)$ parameter has been developed by Miller [48], and calculated according to:

$$
R_{c}=4 \pi \times A / P^{2}, \text { where }
$$

$(A)$ is the basin area, and $(P)$ is the perimeter. If $R_{c}$ is close 1.0, the shape of catchment is circular. Low, medium, and high values of $R_{c}$ indicate young, mature, and old stages of geomorphic development of the watershed.

\subsection{Tools, Data, and Multivariate Statistical Techniques}

\subsubsection{Digital Elevation Model and Morphometric Parameters}

Morphometric analysis for prioritization was conducted using the ASTER Global Digital Elevation Model (TEM) of the National Aeronautic and Space Administration (NASA). The DEM is projected to the Universal Transverse Mercator (UTM) project system, Zone $36 \mathrm{~N}$ using Arc GIS (10.1) software. The W. Mujib-Wala, and the 76 sub-watersheds were delineated initially using topographic maps (Scale 1:50,000). Then ASTER DEM was employed to demarcate the final boundaries of the W. Mujib-Wala and the 76 sub-watersheds (Figure 2). The drainage network for the entire watershed and the sub-watershed were extracted using ASTER DEM (30 m resolution) and the Arc Hydro tool provided by Arc GIS software. Stream order was designated using the stream ordering system developed by Horton [41] and elaborated by Strahler (1964). The W. Mujib-Wala is classified as a seventh-order drainage basin (Figure 3) [42]. Fifteen morphometric 


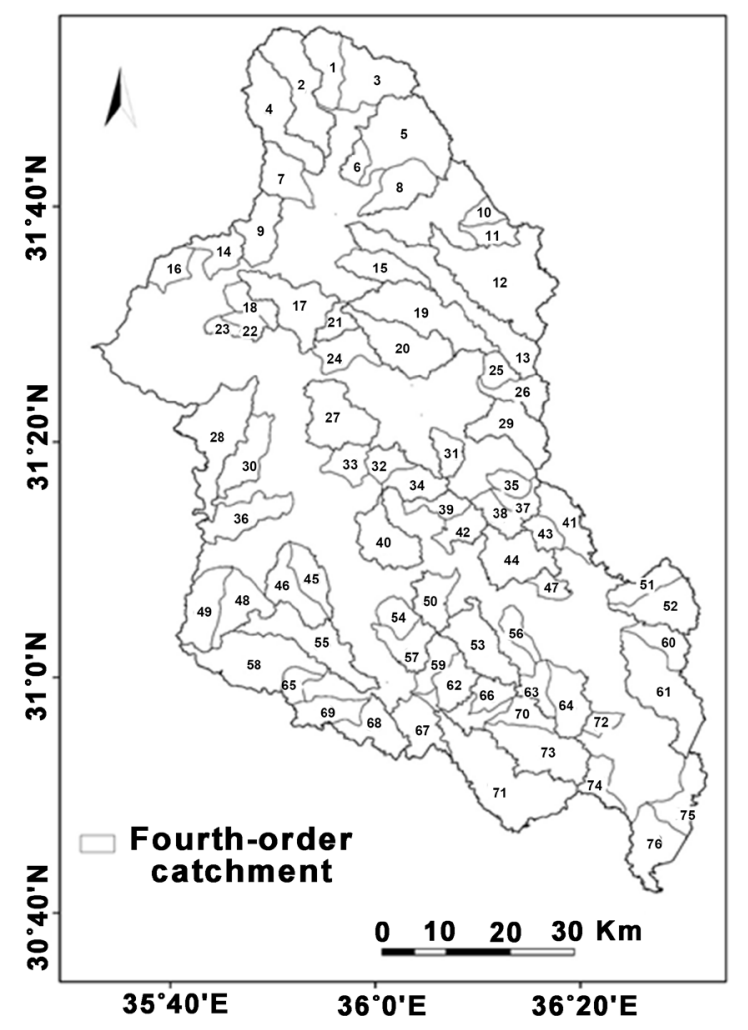

Figure 2. Fourth-order sub-basins.

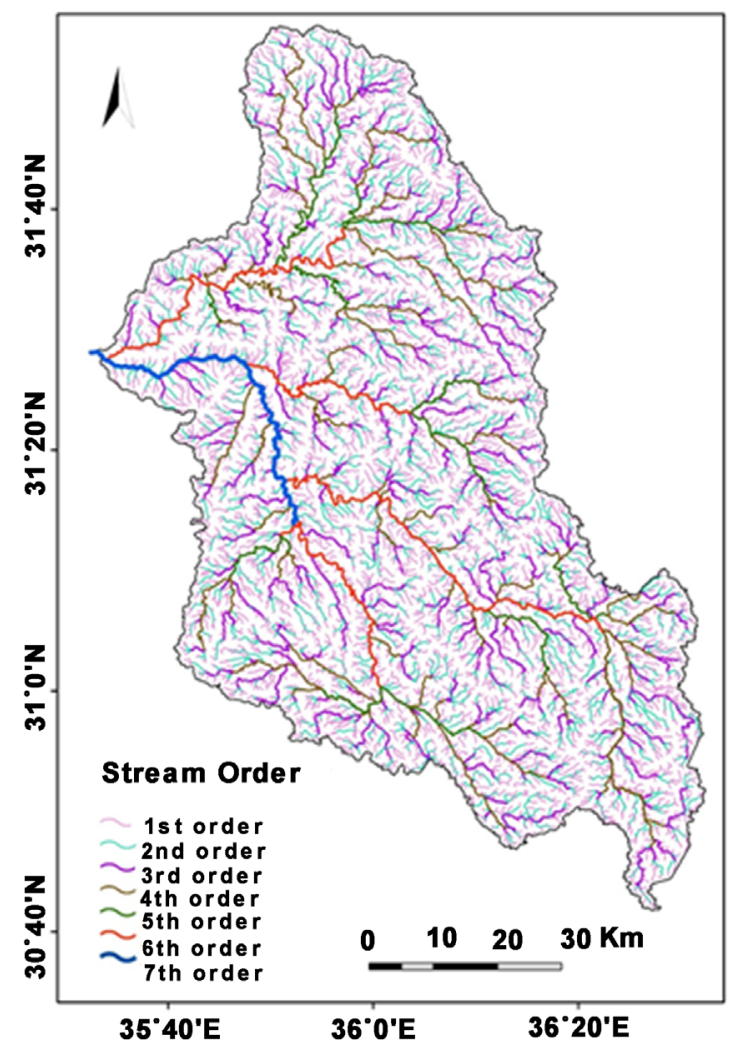

Figure 3. Stream order. 
parameters were computed using DEM, GIS, and the standard formulae developed elsewhere [22] [41] [42] [45] [49]. Moreover, five basic parameters, five linear parameters, and five shape parameters were considered in prioritization of the 76 sub-watersheds based on morphometric analysis as illustrated earlier (Table 1). Linear parameter comprise the Bifurcation ratio $\left(R_{b}\right)$, Drainage density $\left(D_{d}\right)$, stream frequency $\left(F_{s}\right)$, texture ratio $\left(T_{r}\right)$, and length of overland flow $\left(L_{o}\right)$. Shape parameters include: shape factor $\left(B_{s}\right)$, circularity ratio $\left(R_{c}\right)$, form factor $\left(R_{f}\right)$, elongation ratio $\left(\mathrm{R}_{\mathrm{e}}\right)$, and compactness coefficient $\left(C_{c}\right)$. Further, the calculated basic parameters are: basin area $(A)$, perimeter $(P)$, number of streams $\left(N_{u}\right)$, basin length $\left(L_{b}\right)$, and stream length $\left(L_{u}\right)$.

\subsubsection{Land Use/Cover, Soil, and Slope Categories Maps}

Using ERDAS Imagine (2015, v. 15), LANDSATE 8 (July 2017), and supervised classification, the Maximum Likelihood Method of classification techniques was employed to classify Land use/cover guided by the classification system proposed by Anderson et al. [50]. The land use/cover classes recognized are: bare land; rainfed farming; irrigated farming, water body (Mujib dam and Wala dam), and irrigation pools, settlement, and major and minor roads. A soil map (Figure 4) was digitized from the National Soil and Land Use maps of Jordan [51]. A slope categories map was derived using ASTER DEM (Figure 5). A rem arkable variation exists in slopes. Slope categories of $0-5,5-10$, and $10-15$ characterized the eastern part of the entire watershed, whereas, slope categories of $15-20,20-30,30-45$, and $>45$ stand out in the western part of the watershed and the faulted-erosional escarpment overlooking the Dead Sea, and along the canyons and major tributaries downstream (Figure 6).

\subsubsection{Multivariate Analysis}

Principal Component Analysis (PCA) and Discriminant Analysis (DA) have been employed in the analysis. The PCA method is often used to analyze a large data matrix present study the 76 sub-watersheds in order to reduce the large number of variables to a small number of composite variables, or principal components (or factors) which are correlated with the erosion risk morphometric parameters. The technique is also designed to compute the correlation matrix to expose the highly loaded variables on each principal component, and how much the variability in the original parameters is explained by each principal component. The Eigen-value indicates how each of the identified components will fit with the data from all the morphometric parameters on all the PCs. Moreover, Discriminant Analysis was used to test statistically the validity of priority classes of sub-watersheds derived based on morphometric analysis, and to determine if they are significantly different from each other. This serves to guide in explaining the regional spatial variations among the fourth-order sub-basins in terms of prioritization. The development of powerful and cost-effective GIS and RS technology enables researchers to extract, measure, 


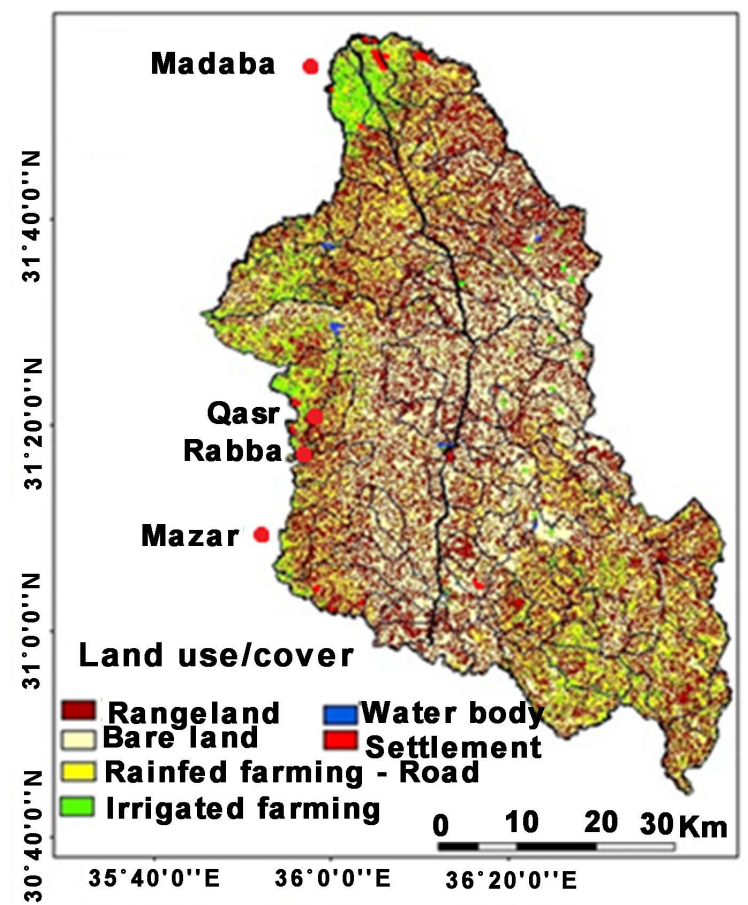

Figure 4. Land use/land cover.

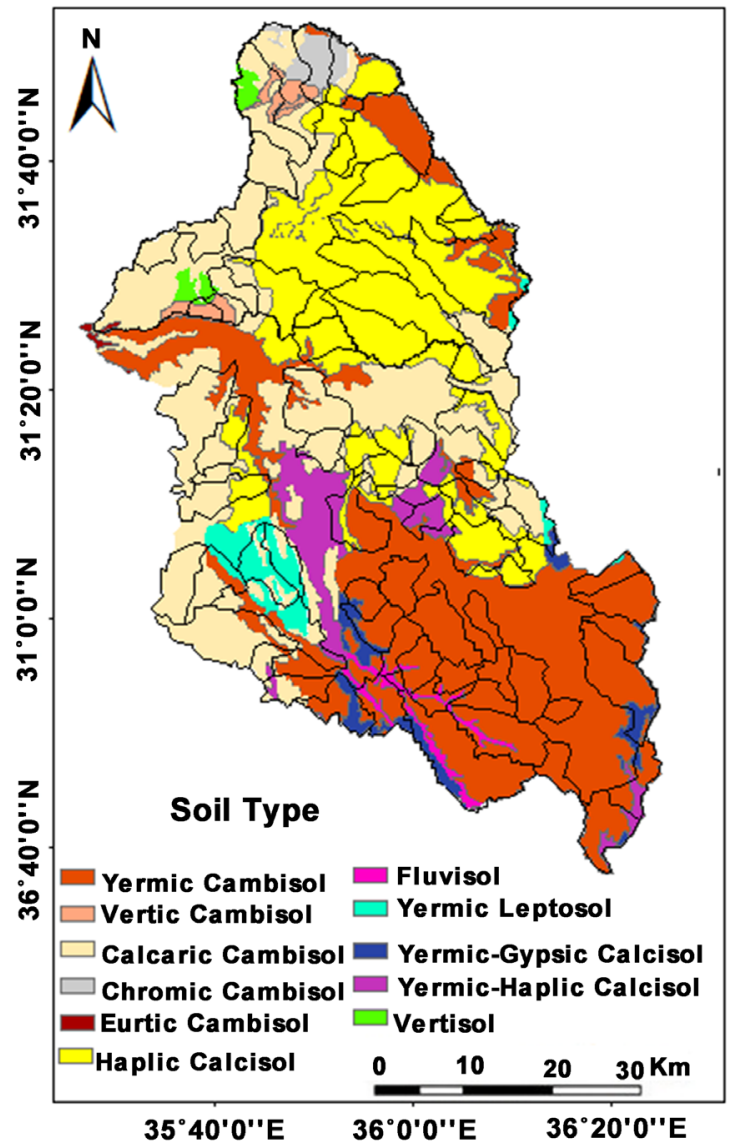

Figure 5. Soil types. 




Figure 6. Slope categories.

compute and precisely process basic, linear, shape, and relief morphometric parameters of drainage basins. Similarly, the availability of free access Digital Elevation Models, i.e. STRM and ASTER DEMS, with a reasonable resolution $(30 \mathrm{~m}$ for ASTER DEM, and $90 \mathrm{~m}$ for STRM DEM)have enhanced quantitative analysis of drainage basin morphometry, thematic mapping, and function to expand the application of quantitative morphometry to other fields of research.

\section{Results and Discussion}

\subsection{Morphometric Analysis}

Basic parameters comprise: $A, P, N_{u} L_{b}$, and $L_{u}$ (Table 1 ). The basin area $(A)$ is a basic morphometric parameter, and constitutes a major component in the hydrological processes [52]. Thus, it has been established by Chorley et al. [53] that the maximum discharge of flood per unit are, is inversely related to the size of the drainage basin. The total area W. Mujib-Wala is $6571.425 \mathrm{~km}^{2}$ (Table 2), and for the 76 sub-basins it varies from $12.12 \mathrm{~km}^{2}$ to $184.99 \mathrm{~km}^{2}$. The basin length $\left(L_{b}\right)$ of W. Mujib-Wala is $136.8 \mathrm{~km}$, and the perimeter is 564.484 . The perimeters for the sub-watersheds range from $17.59 \mathrm{~km}$ (Sub-basin no. 23) to $153.38 \mathrm{~km}$ (Sub-basin no. 13). Sub-basin no. 13 is the longest in basin length $(38.19 \mathrm{~km}$ ), while Sub-basin no. 23 is the shortest $(5.42 \mathrm{~km})$. W. Mujib-Wala is classified as a seventh-order catchment, whereas the delineated 76 sub-catchments 
Table 2. Morphometric characteristics of W. Mujib-Wala Watershed.

\begin{tabular}{|c|c|c|c|c|c|c|c|c|c|}
\hline $\begin{array}{l}\text { Par. } \\
\text { no. }\end{array}$ & Morphometric parameters & & & & tream & order & & & \\
\hline I & Linear Parameters & Total & & & & & & & \\
\hline & Stream order & & I & II & III & IV & $\mathrm{V}$ & VI & VII \\
\hline 1 & No. of streams $\left(N_{u}\right)$ & 7948 & 6167 & & & & & & \\
\hline 2 & Stream length $\left(L_{u}\right)(\mathrm{Km})$ & 9216.34 & 4637.76 & $\begin{array}{c}2235 . \\
5\end{array}$ & $\begin{array}{c}1193 . \\
3\end{array}$ & $\begin{array}{c}595.4 \\
6\end{array}$ & $\begin{array}{c}263.7 \\
2\end{array}$ & 227.4 & 63.2 \\
\hline 3 & $\begin{array}{c}\text { Mean stream length }\left(L_{s m}\right) \\
(\mathrm{Km})\end{array}$ & & 0.752 & 1.634 & 3.788 & 7.835 & $\begin{array}{c}16.48 \\
2\end{array}$ & 45.4 & 63.2 \\
\hline & Stream Length ratio $\left(R_{L}\right)$ & & & II/I & $\mathrm{III} / \mathrm{II}$ & IV/III & $\mathrm{V} / \mathrm{IV}$ & $\mathrm{VI} / \mathrm{V}$ & VII/VI \\
\hline & & & & 0.482 & 0.543 & 0.499 & 0.443 & 0.86 & 0.27 \\
\hline & & & & II/I & III/II & IV/III & $\mathrm{V} / \mathrm{IV}$ & $\mathrm{VI} / \mathrm{V}$ & VII/VI \\
\hline & Bifurcation ratio $\left(R_{b}\right)$ & & 4.508 & 4.343 & 4.145 & 4.750 & 3.200 & 5.000 & \\
\hline 4 & Mean bifurcation ratio $\left(R_{b m}\right)$ & 4.324 & & & & & & & \\
\hline 5 & RHO coefficient $(\rho)$ & 0.120 & & & & & & & \\
\hline 6 & $\begin{array}{l}\text { Length of overland flow } \\
\qquad\left(\mathrm{L}_{\mathrm{o}}\right) \mathrm{Km}\end{array}$ & 0.701 & & & & & & & \\
\hline II & Areal Parameters & & & & & & & & \\
\hline 7 & Basin area $(A)\left(\mathrm{Km}^{2}\right)$ & 6571.425 & & & & & & & \\
\hline 8 & Basin length $\left(L_{b}\right) \mathrm{Km}$ & 136.840 & & & & & & & \\
\hline 9 & Basin perimeter $(P)(\mathrm{Km})$ & 564.484 & & & & & & & \\
\hline 10 & Form factor ratio $\left(R_{f}\right)$ & 0.351 & & & & & & & \\
\hline 11 & Drainage texture $(T)$ & 1.696 & & & & & & & \\
\hline 12 & Circularity ratio $\left(R_{c}\right)$ & 0.259 & & & & & & & \\
\hline 13 & Elongation ratio $\left(R_{e}\right)$ & 0.668 & & & & & & & \\
\hline 14 & Texture ratio $\left(T_{r}\right)$ & 14.080 & & & & & & & \\
\hline 15 & Stream frequency $\left(F_{s}\right)$ & 1.209 & & & & & & & \\
\hline 16 & $\begin{array}{l}\text { Drainage density }\left(D_{d}\right) \\
\qquad\left(\mathrm{Km} / \mathrm{Km}^{2}\right)\end{array}$ & 1.403 & & & & & & & \\
\hline 17 & Shape index $\left(B_{s}\right)$ & 2.849 & & & & & & & \\
\hline 18 & $\begin{array}{l}\text { Constant of channel } \\
\text { maintenance }(C)\end{array}$ & 0.713 & & & & & & & \\
\hline 19 & Compactness coefficient $\left(C_{c}\right)$ & 3.929 & & & & & & & \\
\hline III & Relief Characteristics & & & & & & & & \\
\hline 20 & $\begin{array}{l}\text { Basin relief }\left(B_{h}\right) \text { or } \\
\text { 'Total relief" }(H)(\mathrm{m})\end{array}$ & 1708.000 & & & & & & & \\
\hline 21 & Relief ratio $\left(R_{r}\right)$ & 12.482 & & & & & & & \\
\hline 22 & Ruggedness number $\left(R_{n}\right)$ & 2.395 & & & & & & & \\
\hline 23 & Dissection index $\left(\mathrm{D}_{\text {is }}\right)$ & 1.338 & & & & & & & \\
\hline 24 & $\begin{array}{l}\text { Melton Ruggedness } \\
\text { Number }\left(\mathrm{M}_{\mathrm{rn}}\right)\end{array}$ & 10.440 & & & & & & & \\
\hline
\end{tabular}


are of fourth order. The total stream length $\left(L_{u}\right)$ of W. Mujib-Wala is 9216.34 $\mathrm{km}$, and the first order streams account for $50.3 \%$ of the total stream length. The linear and shape parameters will be discussed in relation to their significance for the hydro-morphological properties of the sub-watersheds. The mean bifurcation ratio $\left(R_{b m}\right)$ for W. Mujib-Wala is 4.324 , and for the 76 sub-basins it ranges from 2.17 to 11.33 (Table 1 ). High $R_{b m}$ values indicate the impact of structural distortions (faults system and dense lineaments) on drainage networks. The drainage density $\left(D_{d}\right)$ for the entire W. Mujib-Wala is 1.403 which denotes moderate to well-drained catchments. An obvious variation in $D_{d}$ values exists between the eastern and southern sub-basins (21 sub-basins, $28.9 \%$ of the total), and the western and the south western sub-basins (18 sub-basins, $23.7 \%$ of the total). Such variation is attributed to relatively high rainfall, and degradation of vegetation cover over the western sub-watersheds, while the southern and south eastern sub-basins are characterized by high relief, steep slopes, and influenced by the Kerak-Al-Fiha faults system and the associated dense lineaments. Thus, greater runoff, and more surface erosion is predicted. There are 39 sub-basins (51.3\% of the total) with $D_{d}$ values $<1.4$. The stream frequency $\left(F_{s}\right)$ of W. Mujib-Wala is 1.209 , and the highest values of $F_{s}(1.77)$ are observed in sub-basin no. 6, while the lowest $F_{s}$ values (1.07) are observed in sub-basins nos. 3 and 51 . High $\mathrm{F}_{\mathrm{s}}$ values are consistent with areas of a high density of lineaments. The texture ratio $\left(T_{r}\right)$ of W. Mujib-Wala is 14.08 , and for the 76 sub-basins, it ranges from 0.40 (sub-basin no. 61) to 1.97 (sub-basin no. 76). The values of $T_{r}$ indicate that these sub-basins are of high runoff. The length of overland flow $\left(L_{o}\right)$ for $W$. Mujib-Wala is 0.701 , whereas, the $L_{o}$ values for the 53 sub-basins range from $0.59 \mathrm{~km}$ (sub-basins no. 23) to $0.80 \mathrm{~km}$ (sub-basin no. 60). Further, the $R_{f}$ value for W. Mujib-Wala is 0.351 , and for the 76 sub-watersheds ranges from 0.09 (sub-basins no. 13), to 0.75 (sub-basin no. 47). Sixty one sub-basins have $\mathrm{R}_{\mathrm{f}}$ values less than 0.4 ( $80 \%$ of the total), which implies that these sub-basins are elongated and more elongated in shape. Therefore, they are characterized as having a low peak flow of longer duration, and consequently exhibit lower probability for severe flooding [13]. The shape factor $\left(B_{s}\right)$ for the entire W. Mujib-Wala is 2.849, while $B_{s}$ values for the 76 sub-basins vary from 1.24 (sub-basin no. 16) to 11.59 (sub-basin 13) which indicate that elongated shape characterizes most of the sub -basins. The elongation ratio $\left(R_{e}\right)$ for Wadi Mujib-Wala catchment is 0.668 , while it ranges from 0.33 (sub-basin no. 54), with seven sub-basins $\left(R_{e}>0.95\right)$ nearly circular in shape, and sub-basin no. 16 is the only circular one. The compactness coefficient $\left(C_{c}\right)$ value for W. Mujib-Wala is 3.929 , whereas the $C_{c}$ values for the 76 sub-basins vary from 2.30 (sub-basin no. 35) to 7.72 (sub-basin no. 13). Therefore high surface erosion dominates these sub-watersheds [41]. The circularity ratio $\left(\mathrm{R}_{\mathrm{c}}\right)$ for the W. Mujib-Wala catchment is 0.259 , whereas $R_{c}$ values for the 76 sub-watersheds range from 0.10 (sub-basin no. 55) to 0.75 (sub-basin no. 35 ). $R_{c}$ values indicate that W. Mujib-Wala and the 76 sub-basins are at the youth-age stage of geomorphic development, and most of them are 
elongated in shape.

\subsection{Prioritization of Sub-Watersheds Based on Morphometric Analysis}

Morphometric analysis of the 76 sub-watersheds of W. Mujib-Wala catchment revealed their relative properties in relation to erodibility and hydrological response. Further, the results of the morphometric analysis method clarified sub-watersheds in terms of priority classes, including higher erosion and soil loss-prone areas which required urgent suitable soil erosion control measures to protect the top soil from further erosion. Very high and high priority classes indicate the greater degree of erosion in specific sub-watersheds, the greater the need to improve available soil and water conservation practices or, the need, to install additional soil conservation structures. The "erosion risk morphometric parameters" utilized to prioritize the 76 sub-basins connected to the $\mathrm{W}$. $\mathrm{Mu}$ jib-Wala are: five linear parameters, e.g. bifurcation ratio $\left(R_{b}\right)$, stream frequency $\left(F_{s}\right)$, drainage density $\left(D_{d}\right)$, length of overland flow $\left(L_{o}\right)$, and texture ratio $\left(T_{r}\right)$. Likewise, five shape parameters are employed in the process and include: shape factor $\left(B_{s}\right)$, form factor $\left(R_{f}\right)$, circularity ratio $\left(R_{c}\right)$, compactness coefficient $\left(C_{c}\right)$, and elongation ratio $\left(R_{e}\right)$. Based on the range of calculated compound parameter $\left(C_{p}\right)$ values (Table 3 ), the 76 sub-watersheds were classified into four priority classes:

1) Very high priority $(20-29)$

2) High priority (30 - 39)

3) Moderate priority (40 - 49)

4) Low priority (50 - 60)

The spatial distribution of priority classes is illustrated in Figure 7 and Table 3. Out of the 76 sub-watersheds, 12 sub-basins ( $15.8 \%$ of the total) came under very high priority (sub-watersheds $6,8,10,25,32,35,47,54,60,63,64$, and 67). The second category of sub-basins is assigned as high priority. It consists of 32 sub-basins ( $42.1 \%$ of the total) as follows: $3,5,11,12,14,16,19,20,21,24,26$, $29,34,37,38,40,41,42,52,53,55,59,62,66,68,69,71,72,73,74,75$, and 76 . The third class of sub-basins is designated as moderate priority class (Figure 7 and Table 3). It comprises of 25 sub-watersheds (32.9\% of the total) as follows: $7,9,13,15,17,22,23,27,28,30,33,36,43,44,45,48,49,50,51,56,57,58,61$, 65 and 70. Sub-basins of this category overlap in the eastern and central part of the W. Mujib-Wala watershed with sub-basins ranked mainly as high priority. About half of these sub-basins are located in the rainfed farming area in the western part of the catchment (Figure 8(a)), while the rest of the sub-basins are located within the degraded rangeland and bare land. Scattered irrigated agriculture is predominant based on pumping wells (Figure $8(\mathrm{~b})$ ). It is also practiced downstream of the W. Wala floodplain and fluvial terraces using surface water from Wala reservoir (Figure 8(c)), the extracted water from springs, and groundwater wells. Similarly, irrigated agriculture is growing rapidly down the 
Table 3. Calculation of compound parameters and prioritized ranks based on morphometric analysis.

\begin{tabular}{|c|c|c|c|c|c|c|c|c|c|c|c|c|}
\hline Sub-watershed no. & $R_{b}$ & $D_{d}$ & $F_{s}$ & $T_{r}$ & $L_{o}$ & $R_{f}$ & $B_{s}$ & $R_{e}$ & $C_{c}$ & $R_{c}$ & $C_{p}$ & Priority rank \\
\hline 1 & 40 & 75 & 64 & 73 & 75 & 36 & 41 & 36 & 54 & 23 & 51.7 & $72 \mathrm{~L}$ \\
\hline 2 & 13 & 74 & 68 & 74 & 74 & 65 & 12 & 65 & 8 & 69 & 52.2 & $74 \mathrm{~L}$ \\
\hline 3 & 20 & 32 & 72 & 61 & 32 & 7 & 70 & 7 & 53 & 24 & 37.8 & $36 \mathrm{H}$ \\
\hline 4 & 10 & 64 & 66 & 70 & 64 & 73 & 4 & 73 & 9 & 68 & 50.1 & $71 \mathrm{~L}$ \\
\hline 5 & 4 & 37 & 45 & 43 & 37 & 11 & 66 & 11 & 34 & 43 & 33.1 & $22 \mathrm{H}$ \\
\hline 6 & 61 & 9 & 1 & 2 & 9 & 25 & 52 & 25 & 65 & 12 & 26.1 & $3 \mathrm{~V} . \mathrm{H}$ \\
\hline 7 & 44 & 53 & 73 & 71 & 53 & 41 & 36 & 41 & 62 & 15 & 48.9 & $67 \mathrm{M}$ \\
\hline 8 & 27 & 14 & 22 & 17 & 14 & 45 & 32 & 45 & 63 & 14 & 29.3 & 8 V.H \\
\hline 9 & 31 & 55 & 69 & 68 & 55 & 24 & 53 & 24 & 37 & 40 & 45.6 & $60 \mathrm{M}$ \\
\hline 10 & 73 & 1 & 4 & 1 & 1 & 33 & 44 & 33 & 66 & 11 & 26.7 & 4 V.M \\
\hline 11 & 65 & 5 & 21 & 8 & 5 & 59 & 18 & 59 & 43 & 34 & 31.7 & $17 \mathrm{H}$ \\
\hline 12 & 3 & 31 & 35 & 33 & 31 & 46 & 31 & 46 & 4 & 73 & 33.3 & $25 \mathrm{H}$ \\
\hline 13 & 6 & 56 & 50 & 51 & 56 & 76 & 1 & 76 & 1 & 76 & 44.9 & $59 \mathrm{M}$ \\
\hline 14 & 42 & 42 & 20 & 23 & 42 & 16 & 61 & 16 & 30 & 47 & 33.9 & $27 \mathrm{H}$ \\
\hline 15 & 19 & 61 & 13 & 24 & 61 & 74 & 3 & 74 & 20 & 57 & 40.6 & $47 \mathrm{M}$ \\
\hline 16 & 59 & 50 & 33 & 40 & 50 & 1 & 76 & 1 & 70 & 7 & 38.7 & $41 \mathrm{H}$ \\
\hline 17 & 16 & 72 & 60 & 69 & 72 & 56 & 21 & 56 & 10 & 67 & 49.9 & $69 \mathrm{M}$ \\
\hline 18 & 55 & 70 & 54 & 64 & 70 & 54 & 23 & 54 & 42 & 35 & 52.1 & $73 \mathrm{~L}$ \\
\hline 19 & 8 & 18 & 55 & 45 & 18 & 72 & 5 & 72 & 6 & 71 & 37 & $34 \mathrm{H}$ \\
\hline 20 & 15 & 27 & 65 & 55 & 27 & 42 & 35 & 42 & 11 & 66 & 38.5 & $39 \mathrm{H}$ \\
\hline 21 & 62 & 44 & 3 & 7 & 44 & 21 & 56 & 21 & 24 & 53 & 33.5 & $26 \mathrm{H}$ \\
\hline 22 & 64 & 73 & 14 & 35 & 73 & 26 & 51 & 26 & 69 & 8 & 43.9 & $54 \mathrm{M}$ \\
\hline 23 & 76 & 76 & 17 & 48 & 76 & 17 & 60 & 17 & 73 & 4 & 46.4 & $63 \mathrm{M}$ \\
\hline 24 & 37 & 51 & 40 & 46 & 51 & 8 & 69 & 8 & 50 & 27 & 38.7 & $42 \mathrm{H}$ \\
\hline 25 & 69 & 16 & 12 & 10 & 16 & 5 & 72 & 5 & 68 & 9 & 28.2 & $6 \mathrm{~V} . \mathrm{H}$ \\
\hline 26 & 38 & 40 & 18 & 20 & 40 & 57 & 20 & 57 & 18 & 59 & 36.7 & $33 \mathrm{H}$ \\
\hline 27 & 14 & 66 & 47 & 54 & 66 & 10 & 67 & 10 & 33 & 44 & 41.1 & $48 \mathrm{M}$ \\
\hline 28 & 9 & 54 & 52 & 53 & 54 & 71 & 6 & 71 & 3 & 74 & 44.7 & $58 \mathrm{M}$ \\
\hline 29 & 22 & 20 & 42 & 30 & 20 & 44 & 33 & 44 & 14 & 63 & 33.2 & $23 \mathrm{H}$ \\
\hline 30 & 35 & 69 & 44 & 56 & 69 & 55 & 22 & 55 & 31 & 46 & 48.2 & $65 \mathrm{M}$ \\
\hline 31 & 68 & 68 & 57 & 63 & 68 & 22 & 55 & 22 & 52 & 25 & 50 & $70 \mathrm{~L}$ \\
\hline 32 & 58 & 4 & 29 & 15 & 4 & 6 & 71 & 6 & 60 & 17 & 27 & $5 \mathrm{~V} . \mathrm{H}$ \\
\hline 33 & 1 & 57 & 67 & 67 & 57 & 14 & 63 & 14 & 67 & 10 & 41.7 & $49 \mathrm{M}$ \\
\hline 34 & 46 & 30 & 48 & 44 & 30 & 34 & 43 & 34 & 49 & 28 & 38.6 & $40 \mathrm{H}$ \\
\hline 35 & 72 & 8 & 19 & 13 & 8 & 20 & 57 & 20 & 76 & 1 & 29.4 & $10 \mathrm{~V} . \mathrm{H}$ \\
\hline 36 & 24 & 38 & 70 & 62 & 38 & 58 & 19 & 58 & 32 & 45 & 44.4 & $56 \mathrm{M}$ \\
\hline 37 & 63 & 29 & 5 & 6 & 29 & 35 & 42 & 35 & 39 & 38 & 32.1 & $19 \mathrm{H}$ \\
\hline 38 & 50 & 33 & 10 & 16 & 33 & 15 & 62 & 15 & 44 & 33 & 31.1 & $16 \mathrm{H}$ \\
\hline 39 & 71 & 63 & 62 & 66 & 63 & 68 & 9 & 68 & 35 & 42 & 54.7 & $76 \mathrm{~L}$ \\
\hline
\end{tabular}




\begin{tabular}{|c|c|c|c|c|c|c|c|c|c|c|c|c|}
\hline 40 & 29 & 28 & 59 & 49 & 28 & 51 & 26 & 51 & 15 & 62 & 39.8 & $44 \mathrm{H}$ \\
\hline 41 & 33 & 13 & 34 & 22 & 13 & 31 & 46 & 31 & 16 & 61 & 30 & $14 \mathrm{H}$ \\
\hline 42 & 49 & 41 & 16 & 19 & 41 & 23 & 54 & 23 & 40 & 37 & 34.3 & $30 \mathrm{H}$ \\
\hline 43 & 74 & 58 & 26 & 41 & 58 & 13 & 64 & 13 & 64 & 13 & 42.4 & $50 \mathrm{M}$ \\
\hline 44 & 23 & 59 & 61 & 65 & 59 & 4 & 73 & 4 & 12 & 65 & 42.5 & $51 \mathrm{M}$ \\
\hline 45 & 45 & 48 & 58 & 58 & 48 & 70 & 7 & 70 & 57 & 20 & 48.1 & $64 \mathrm{M}$ \\
\hline 46 & 17 & 71 & 75 & 75 & 71 & 64 & 13 & 64 & 26 & 51 & 52.7 & $75 \mathrm{~L}$ \\
\hline 47 & 67 & 2 & 2 & 3 & 2 & 3 & 74 & 3 & 51 & 26 & 23.3 & 2 V.H \\
\hline 48 & 26 & 62 & 41 & 47 & 62 & 39 & 38 & 39 & 47 & 30 & 43.1 & $53 \mathrm{M}$ \\
\hline 49 & 34 & 52 & 53 & 52 & 52 & 43 & 34 & 43 & 61 & 16 & 44 & $55 \mathrm{M}$ \\
\hline 50 & 47 & 60 & 74 & 72 & 60 & 19 & 58 & 19 & 38 & 39 & 48.6 & $66 \mathrm{M}$ \\
\hline 51 & 60 & 24 & 71 & 59 & 24 & 66 & 11 & 66 & 45 & 32 & 45.8 & $61 \mathrm{M}$ \\
\hline 52 & 25 & 35 & 28 & 28 & 35 & 38 & 39 & 38 & 27 & 50 & 34.3 & $31 \mathrm{H}$ \\
\hline 53 & 18 & 36 & 23 & 26 & 36 & 48 & 29 & 48 & 7 & 70 & 34.1 & $28 \mathrm{H}$ \\
\hline 54 & 48 & 7 & 6 & 4 & 7 & 2 & 75 & 2 & 75 & 2 & 22.8 & $1 \mathrm{~V} . \mathrm{H}$ \\
\hline 55 & 12 & 39 & 30 & 29 & 39 & 75 & 2 & 75 & 2 & 75 & 37.8 & $38 \mathrm{H}$ \\
\hline 56 & 54 & 45 & 32 & 38 & 45 & 61 & 16 & 61 & 72 & 5 & 42.9 & $52 \mathrm{M}$ \\
\hline 57 & 43 & 65 & 51 & 57 & 65 & 27 & 50 & 27 & 29 & 48 & 46.2 & $62 \mathrm{M}$ \\
\hline 58 & 7 & 49 & 36 & 42 & 49 & 67 & 10 & 67 & 13 & 64 & 40.4 & $46 \mathrm{M}$ \\
\hline 59 & 52 & 25 & 38 & 32 & 25 & 52 & 25 & 52 & 41 & 36 & 37.8 & $37 \mathrm{H}$ \\
\hline 60 & 51 & 3 & 25 & 11 & 3 & 49 & 28 & 49 & 46 & 31 & 29.6 & $11 \mathrm{~V} . \mathrm{H}$ \\
\hline 61 & 5 & 10 & 76 & 76 & 10 & 69 & 8 & 69 & 22 & 55 & 40 & $45 \mathrm{M}$ \\
\hline 62 & 41 & 23 & 37 & 31 & 23 & 18 & 59 & 18 & 59 & 18 & 32.7 & $21 \mathrm{H}$ \\
\hline 63 & 56 & 15 & 11 & 9 & 15 & 37 & 40 & 37 & 36 & 41 & 29.7 & 12 V.H \\
\hline 64 & 30 & 19 & 24 & 18 & 19 & 29 & 48 & 29 & 58 & 19 & 29.3 & 9 V.H \\
\hline 65 & 70 & 67 & 8 & 27 & 67 & 53 & 24 & 53 & 71 & 6 & 44.6 & $57 \mathrm{M}$ \\
\hline 66 & 57 & 17 & 15 & 12 & 17 & 28 & 49 & 28 & 56 & 21 & 30 & $13 \mathrm{H}$ \\
\hline 67 & 36 & 21 & 27 & 21 & 21 & 9 & 68 & 9 & 17 & 60 & 28.9 & 7 V.H \\
\hline 68 & 28 & 47 & 56 & 50 & 47 & 12 & 65 & 12 & 19 & 58 & 39.4 & $43 \mathrm{H}$ \\
\hline 69 & 39 & 6 & 46 & 25 & 6 & 50 & 27 & 50 & 55 & 22 & 32.6 & $20 \mathrm{H}$ \\
\hline 70 & 66 & 46 & 63 & 60 & 46 & 62 & 15 & 62 & 48 & 29 & 49.7 & $68 \mathrm{M}$ \\
\hline 71 & 2 & 34 & 39 & 39 & 34 & 30 & 47 & 30 & 5 & 72 & 33.2 & $24 \mathrm{H}$ \\
\hline 72 & 75 & 12 & 7 & 5 & 12 & 40 & 37 & 40 & 74 & 3 & 30.5 & $15 \mathrm{H}$ \\
\hline 73 & 11 & 11 & 49 & 37 & 11 & 47 & 30 & 47 & 21 & 56 & 32 & $18 \mathrm{H}$ \\
\hline 74 & 53 & 26 & 9 & 14 & 26 & 60 & 17 & 60 & 28 & 49 & 34.2 & $29 \mathrm{H}$ \\
\hline 75 & 32 & 22 & 43 & 36 & 22 & 63 & 14 & 63 & 23 & 54 & 37.2 & $35 \mathrm{H}$ \\
\hline 76 & 21 & 43 & 31 & 34 & 43 & 32 & 45 & 32 & 25 & 52 & 35.8 & $32 \mathrm{H}$ \\
\hline
\end{tabular}

dam of the W. Mujib on the floodplain, and fluvial terraces using surface water from the reservoir and pumping wells as well. The fourth priority class of sub-basins is assigned a low priority (Figure 7 and Table 3). It consists of 7 


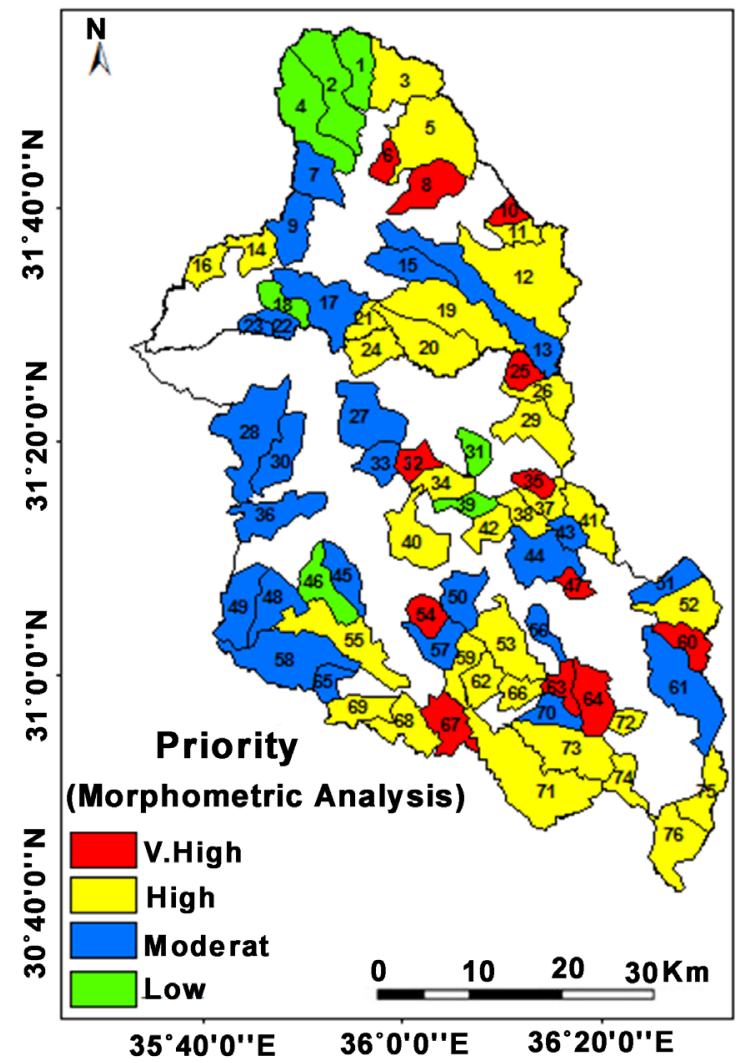

Figure 7. Four priority classes.

sub-watersheds ( $9.2 \%$ of the total) as follows: $1,2,4,18,31,39$, and 46 . Five of these sub-basins represent typical rainfed and irrigated farming areas on flat-undulating terrain in the northern part of the catchment east of Madaba, and the eastern part of the watershed. The expansion of cereals cultivation over the marginal areas and rangeland (annual rainfall varies from 200 to $250 \mathrm{~mm}$ ) accelerate soil erosion [2]. Irrespective of scattered irrigated agriculture, the eastern part of W. Mujib-Wala forms a poor grazing land with high soil erodibility. Thus repetitive intense rainstorms over southern Jordan [54] initiate severe soil erosion where the vegetation cover is highly degraded. Additionally, degraded rangeland and bare land occupy large areas of the watershed due to the low amount of rainfall, marginality (the dominance of semiarid and arid conditions), which in turn accelerate soil erosion. All sub-watersheds ranked under very high and high priority have greater erosional potential with a high erosion risk. Consequently, they are considered potential areas for adapting soil conservation measures [21]. Rill and gully erosion, and landslide activity are common on steep slopes $\left(15^{\circ}-25^{\circ}\right.$, and $\left.>30\right)$ where soft carbonate rocks of low shearing resistance are exposed. Sheet erosion is also active on gentle slopes $\left(0^{\circ}-5^{\circ}\right)$ in the rainfed areas over the table lands bordering the canyons of W. Mujib-Wala downstream (i.e., the Qasr-Rabba, south east of Madaba, and Dhiban areas) where the annual rainfall ranges from 285 to $350 \mathrm{~mm}$. Geological, morphological 




Figure 8. Rainfed farming on gentle/undulating slopes (a); pumping wells irrigated farming (b) and irrigated farming based on the Wala reservoir (c). Source: Google Earth Bro 1/1/2017.

and anthropogenic factors account for high soil erosion rates. Among these are: the Kerak Al-Fiha fault system and the associated dens lineaments, the northwest-southeast fault system which influenced the central part of the W. Mujib-Wala, the W. Wala fault, the W. Az-Za'faran fault, W. Zerqa Ma'an fault, and the W. Al-Falij fault, and the connected dense lineaments [55].

Morphological factors contributing to high soil erosion loss are: high relief, steep and long slopes of $10^{\circ}-15^{\circ}, 15^{\circ}-20^{\circ}, 20^{\circ}-30^{\circ}$ and $>30^{\circ}$ slope categories. Sub-watersheds classified as high priority groups display high soil erosion rates and high sediment loads discharging into the Wala dam and the Mujib dam [16] [17]. These 44 sub-basins which are influenced by such processes ( $58 \%$ of the total) need urgent attention for implementing soil conservation practice. The long periods of resource exploitation, land use abuse, and the deterioration of vegetation cover have functioned to maximize soil erosion since the Neolithic and Chalcalithic periods. The existence of agricultural stone terraces over the rainfed highlands is an indicator of severe soil erosion at least since the Nabatean period some 3000 years ago [56].

\subsection{Proposed Soil and Water Conservation Measures}

Morphometric analysis using erosion risk parameters was employed to prioritize 76 fourth-order sub-watersheds for soil and water conservation. The compound parameter values were calculated and the prioritization rating is given in Table 
3. The effect of land use/cover, slope, soil, and relief were considered in order to propose appropriate soil and water conservation measures. Despite overlapping observed in the spatial distribution of sub-basins connected to each priority class, geological, morphological, and anthropogenic factors including history of land utilization (i.e. past and present abuse of land resources), were responsible for such a pattern of priority classes distribution. According to their ranking priority, sub-basin 54 with a compound parameter $\left(C_{p}\right)$ value of 22.8 receives the highest priority rank, while the next in priority (Table 3 ) is sub-watershed 47 , having a value of 23.3. Likewise, sub-basins nos. 6 and 10 rank third and fourth in the priorities with $C_{p}$ values of 26.1 and 26.7 respectively. "Highest priority implies the greater degree of erosion potential associated in the particular area for adaptation of soil conservation measures" [21]. It is evident in this study that sub-watersheds nos. $6,10,25,52,60$, and 64 , for example, are designated as very high priority for soil conservation measures (Figure 7 and Table 3). Sub-basins nos. 6, 10, and 25 represent deeply dissected streams cut into Ajlune group limestone [37], where the Chromic Camisol type developed. These sub-watersheds constitute desertified rangeland and bare land. Over-grazing, recurrent droughts, the expansion of towns and rural settlements at the expense of rainfed areas, and degradation of vegetation cover caused severe soil erosion, and high sediment yield discharge into the Wala and Mujib reservoirs. Similarly sub-watersheds 52, 60, and 64 represent undulating terrain developed on limestone, with slope categories of 0 - 5 and 5 - 10. The soil type is restricted to Yermic-Haplic Calcisol, the prime land use activity is poor grazing and scattered irrigated farming based on underground water which supports the livelihood of local people. Structural conservation measures, comprise, stone bunds, contour stone terraces, and water conservation measures; these are on both gentle and steep slopes connected to sub-watersheds classified under very high and high priority. Rangeland management is essential to protect the present degraded vegetation cover, and redeveloping of the natural vegetation by means of seeding specific sub-basins with suitable grasses, and planning for efficient range land management. Expanding tree-planting of drought-resistance species is also recommended [57].

The high priority class of sub-watersheds occupy the northeast, east and southeastern part of the W. Mujib-Wala watershed. The main land use activity here is an overlapping of rainfed farming, rangeland, and scattered irrigated cultivation based on pumping wells. Sub-basins 3, 12, 16, 20, 34, 40, 55, 62, 68, 75 are an example (Figure 7 and Table 3). Exploitation of land resources over the last 3000 years [56] has contributed to several serious environmental problems, i.e., destruction of vegetation cover, severe soil erosion loss, continuous crop yield and livestock decline, and suffering of the local people. The most noticeable land use activity is the expansion of rainfed farming and irrigated agriculture in the west towards the marginal and rangeland in the east, and the increase in irrigated farming. Thus, a decrease in rangeland, and increase in bare land have oc- 
curred. Appropriate check dams, terracing and bunding are suitable conservation measures on sloppy land that are proposed, and efficient rangeland management is recommended to reduce soil erosion loss and sediment yields. Moderate and low priority sub-watersheds are located on the broad table-land bordering the deeply dissected wadis cut in Ajlune group limestone and basalt in the western part of the entire catchment, and the gentle-undulating terrain in the northern part. The dominant slope categories are: $0^{\circ}-5^{\circ}, 5^{\circ}-10^{\circ}$, and $10^{\circ}-15^{\circ}$. Rainfed and irrigated farming are the main land use activity. Examples of these 32 sub-basins ( $42 \%$ of the total area) are: 7, 17, 27, 28, 30, 48, 49 (moderate priority), and sub-basins nos. 1, 2, 4, 18, 46, (low priority) (Figure 7). Length and steepness of slopes in the moderate and low priority sub-watersheds can be modified through the construction of contour stone terraces locally termed "Mastaba" accompanied by tree-planting on slopes ranging from $3^{\circ}$ to $25^{\circ}$ [13] [58]. Stone terraces should be placed in long rows along the contour at various intervals depending on the length and steepness of slope [58]. Additionally, bench terraces can be constructed on slopes even steeper than $25^{\circ}$, and when stones are not sufficiently available to build contours stone terraces. Such conservation techniques have been adopted by the rainfed farmers since the Nabatean period, some 3000 years ago [56]. Structural conservation measures should be integrated with technology enhancing farming practices, i.e., rotation, strip cropping, contour strip intercropping cultivation [59], and contour plowing so as to reduce soil erosion loss, increase soil moisture at a farm, and improve crop productivity. The previous technique can be proposed for soil and water conservation in the sub-watersheds dominated by rainfed farming.

\subsection{Multivariate Analysis}

\subsubsection{Principal Component Analysis (PCA)}

Principal Component Analysis was performed to assess the effective basic and erosion risk morphometric parameters in watershed prioritization for soil and water conservation, and to illustrate the physical behavior and relationships between the basic and erosion risk parameters for a semi-arid catchment. Principal component analysis utilized as a component loading matrix which expresses numerically the level of relationship between them and the original erosion risk morphometric parameters. The weights of the original parameters in each component are called "loadings", and each component is correlated with certain erosion risk parameters. Besides interpreting the processes that generate the observed relationship between the chosen variables, PCA also provides a simplified data matrix known as the component score (or weightings) matrix [60]. Through Principal Component Analysis, three efficient components were extracted, and the 16 basic and erosion risk parameters were reduced to these three components. The relationships between the rotated components and the original morphometric parameters are occasionally incorporated in the component loading matrix. These relationships are expressed in terms of the percentage 
contributed to the variance in the original data. It is also obvious that each component is more strongly correlated to some parameters that are considered more effective compared to others. Table 4 illustrates the Eigen-values, variance proportion, and cumulative proportion variance. Further, the results showed $88 \%$ of variances represented by 12 parameters which include five basic parameters, and one erosion risk parameter are highly loaded on $\mathrm{PC}_{1}$ and $\mathrm{PC}_{3}$. Most of the basic and erosion risk parameters exhibit loading values $>0.9$, whereas $R_{c}, F_{s}$ and $T_{r}$ parameters display loading values $<0.9(0.798,0.898$, and 0.703 respectively). The higher the loadings, the stronger the correlation. Three major components were resulted based on PCA analysis and accounts for $88 \%$ of the total variance explained by the basic, and erosion risk parameters and the $C_{p}$ parameter. The most effective variable in $\mathrm{PC}_{1}$ to $\mathrm{PC}_{3}$ are shown by bold font in Table 5 . It is clear that stream length $\left(L_{u}\right)$, basin area $(A)$, basin length $\left(L_{b}\right)$, stream number $\left(N_{u}\right)$, Perimeter $(P)$, and circularity ratio $\left(R_{c}\right)$ have the most variance proportions $(41.85 \%)$, and turn to greatest effect on the first component. Likewise, drainage density $\left(D_{d}\right)$, length of overland flow $\left(L_{o}\right)$, texture ratio $\left(T_{r}\right)$, Stream frequency $\left(F_{s}\right)$, and the compound parameter $\left(C_{p}\right)$ have the greatest effect on the second component $\left(\mathrm{PC}_{2}\right)$, which comprises $25.1 \%$ of variance proportions. Additionally, form factor $\left(R_{f}\right)$ and elongation ration $\left(R_{e}\right)$ have the greatest effect on the third component $\left(\mathrm{PC}_{3}\right)$, which contributes $21.1 \%$ of variance proportions. Variable loadings show that one of the erosion risk parameters is accommodated within $\mathrm{PC}_{1}$, while six parameters including the $C_{p}$ parameter are associated with $\mathrm{PC}_{2}$ and $\mathrm{PC}_{3}$ where both explain $46.2 \%$ of the total variance. The erosion risk parameters mentioned above explain more than half of the total variance, although the $\mathrm{R}_{\mathrm{c}}$ parameter is associated with $\mathrm{PC}_{1}$. The component loadings/show that $P C_{1}$ describes parameters related to the sub-watersheds drainage network ( $L_{u}, A, L_{b}, N_{u}$, and $P$ ). Consequently, the $\mathrm{PC}_{1}$ is labeled as a "sub-watershed size "component. The second component corresponds to drainage density $\left(D_{d}\right)$, length of overland flow $\left(L_{o}\right)$, texture ratio $\left(T_{r}\right)$, and stream frequency $\left(F_{s}\right)$. Thus, the second component reflects the dissection/hydrographic component. The

Table 4. Total variance explained by the component.

\begin{tabular}{|c|c|c|c|c|c|c|c|c|c|}
\hline \multirow{2}{*}{ Component } & \multicolumn{3}{|c|}{ Initial Eigenvalues } & \multicolumn{3}{|c|}{ Extraction Sums of Squared Loadings } & \multicolumn{3}{|c|}{ Rotation Sums of Squared Loadings } \\
\hline & Total & $\begin{array}{c}\% \text { of } \\
\text { Variance }\end{array}$ & Cumulative \% & Total & $\begin{array}{c}\% \text { of } \\
\text { Variance }\end{array}$ & Cumulative \% & Total & $\begin{array}{c}\% \text { of } \\
\text { Variance }\end{array}$ & Cumulative \% \\
\hline 1 & 8.160 & 50.999 & 50.999 & 8.160 & 50.999 & 50.999 & 6.696 & 41.852 & 41.852 \\
\hline 2 & 3.594 & 22.463 & 73.462 & 3.594 & 22.463 & 73.462 & 4.021 & 25.132 & 66.984 \\
\hline 3 & 2.340 & 14.625 & 88.087 & 2.340 & 14.625 & 88.087 & 3.377 & 21.103 & 88.087 \\
\hline 4 & .903 & 5.645 & 93.732 & & & & & & \\
\hline 5 & .621 & 3.880 & 97.612 & & & & & & \\
\hline 6 & .216 & 1.348 & 98.960 & & & & & & \\
\hline
\end{tabular}


Table 5. Rotated component matri.

\begin{tabular}{|c|c|c|c|}
\hline \multirow{2}{*}{$\begin{array}{l}\text { Morpho. } \\
\text { Parameters }\end{array}$} & \multicolumn{3}{|c|}{ Component } \\
\hline & 1 & 2 & 3 \\
\hline $\mathbf{R}_{\mathrm{b}}$ & $-0.882-$ & $-0.186-$ & -0.069 \\
\hline $\mathrm{D}_{\mathrm{d}}$ & 0.003 & 0.918 & $-0.002-$ \\
\hline $\mathrm{F}_{\mathrm{s}}$ & 0.246 & 0.898 & 0.100 \\
\hline $\mathrm{T}_{\mathrm{r}}$ & 0.336 & 0.703 & 0.138 \\
\hline $\mathrm{L}_{\mathrm{o}}$ & 0.003 & 0.918 & $-0.002-$ \\
\hline $\mathbf{R}_{\mathrm{f}}$ & 0.211 & 0.124 & 0.967 \\
\hline $\mathrm{B}_{\mathrm{s}}$ & $-0.211-$ & $-0.124-$ & $-0.967-$ \\
\hline $\mathbf{R}_{\mathrm{e}}$ & 0.211 & 0.124 & 0.967 \\
\hline $\mathrm{C}_{\mathrm{c}}$ & -0.799 & $-0.091-$ & $-0.297-$ \\
\hline $\mathbf{R}_{c}$ & 0.799 & 0.091 & 0.297 \\
\hline $\mathrm{C}_{\mathrm{p}}$ & $-0.023-$ & 0.943 & 0.316 \\
\hline $\mathrm{L}_{\mathrm{u}}$ & 0.963 & 0.035 & 0.075 \\
\hline $\mathrm{L}_{\mathrm{b}}$ & 0.832 & 0.147 & 0.458 \\
\hline $\mathrm{N}_{\mathrm{u}}$ & 0.940 & 0.015 & 0.021 \\
\hline $\mathbf{P}$ & 0.951 & 0.112 & 0.206 \\
\hline A & 0.963 & 0.105 & 0.075 \\
\hline
\end{tabular}

Note: Figures in bold indicate the variables with strong loadings on the corresponding components (represent the reduced 16 variables).

third component corresponds to the form factor $\left(R_{f}\right)$, and elongation ratio $\left(R_{e}\right)$; therefore this component refers to the sub-watershed "Shape component."

\subsubsection{Discriminant Analysis (DA)}

It has been argued that prioritization based on the morphometric analysis method by utilizing the erosion risk morphometric parameters is time consuming in comparison with other approaches including the Principal Component Analysis approach, which allows for more effective parameters for prioritizing watersheds [24]. However, a prioritization for the Zarqa River has been carried out recently based on the morphometric analysis method and the PCA approach [13]. The output revealed that both methods did not produce similar results as stated earlier by Gajbhiye and Sharma [24] in a study on Shakkar River Catchment, Madhya Pradesh, India. Such disagreement in the results related to the two case studies is probably attributed to differences in physical conditions between Central India and Northern Jordan. The present study introduces a prioritization scheme for 76 sub-watersheds on the basis of the morphometric analysis method (the linear and shape parameters), and to test the achieved priority classes using Discriminant Analysis (DA) technique. The resultant priority classes displayed in Figure 7 and Table 3, are proved to be statistically valid. Consequently, the utilization of the morphometric analysis method is jus- 
tified as a successful method of prioritization. Statistical validation also implies that erosion risk morphometric parameters are efficient parameters in prioritization of watersheds for soil and water conservation measures. The intention of statistical testing of sub-watersheds pertaining to the four priority classes is to test the hypothesis that there are significant differences between the four priority classes achieved earlier, and if the hypothesis can be accepted to establish a system of coordinate axis which discriminates between the four priority classes identified (1: low priority to 4 : very high priority). Statistical analysis was conducted on four data matrices representing the four priority groups (i.e., $7 \times 11$; $25 \times 11: 32 \times 11$; and $12 \times 11$ ) with the associated ranking values (connected to linear and shape parameters), including the $\mathrm{Cp}$ scores. The $\mathrm{F}$ test of Wilks Lambda obtained is F ratio 174.9 , with the degree of freedom V1 $=3$ and V2 $=$ 72. Referring to the table of percentage points of the F-distribution, with $\mathrm{V} 1=3$ and V2 $=72$, it is found that at 99.9 percent of confidence, the tabulated value is 5.78 , which is significantly exceeded by the computed F ratio (174.9). Subsequently, their is a great significant difference between each of the priority groups (very high, high, moderate, and low), and the four priority classes are completely separate and distinct. Moreover, 98.0 percent of the difference between the four the four priority classes is attributed to discriminant function 1 (93.7 percent) and discriminant function 2 (4.3 percent). Further, it was observed that the discriminant function 1 is positively correlated with six erosion risk morphometric parameters (the linear and shape parameters). Correlation values range from 0.413 to 0.999 , and the $C_{p}$ values are very strongly correlated with discriminant function 1 (0.970). By contrast, the correlation of discriminant function 2 with erosion risk parameters is relatively weak $(0.17-0.237)$. The scores of each sub-basin of the priority groups (shown in Table 3, and illustrated in Figure 7) on the discriminant function 1 and 2 were plotted in Figure 9. The plot displays completely disconnected priority clusters. The present results show that

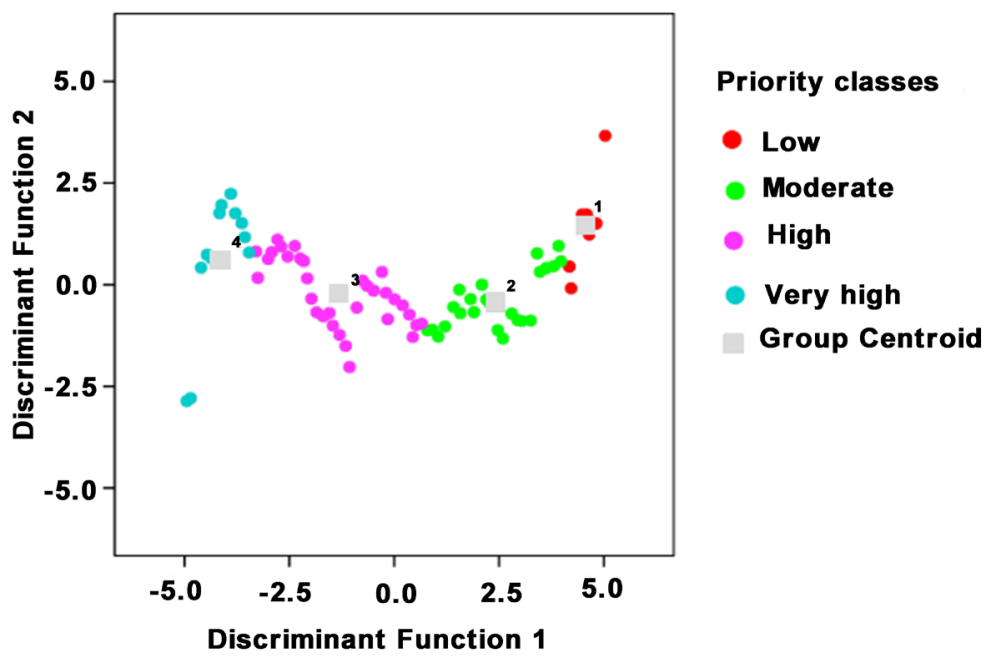

Figure 9. Results of discriminant function 1 and 2 grouping: the four priority classes are completely separated. 
prioritization based on morphometric analysis is substantiated to be statistically valid, consistent and reliable, and of high capacity using GIS tools. The potential of the morphometric analysis approach as developed an elaborated earlier [8] [9] [22] is highly appreciated, and thus is, recommended for prioritization research.

\section{Conclusions}

Soil erosion by water has seriously threatened rainfed farming and rangeland over most of the terrain units of the W. Mujib-Wala watershed. High soil erosion rates have also increased sediment supply to the Mujib and Wala reservoirs during exceptionally heavy rainstorms, which are common in southern Jordan. The GIS-based morphometric analysis method and RS, were employed to prioritize 76 sub-watersheds, and the relationship of major components determined based on PCA to erosion risk morphometric parameters was explored. Then efficient conservation measures were suggested, especially for sub-watersheds where rainfed farming and grazing are practiced. Four priority classes were recognized: very high (12 sub-basins, $15.8 \%$ of the total), high (32 sub-basins, $42.1 \%$ of the total), moderate (25 sub-basins, $32.9 \%$ of the total, and low (7 sub-watersheds, $9.2 \%$ of the total). Moreover, 44 sub-watersheds ( $57.9 \%$ of the total) are ranked under very high and high priority, and are subject to high erosion risk, thus creating an urgent need for applying soil and water conservation measures so as to maintain rainfed farming and grazing sustainability. Based on $C_{p}$ values and ranking priority, sub-watershed 54 with a $C_{p}$ score of 22.8 receives the highest priority. The next in the priority list is sub-basin 47 , having a value of 23.3 (Table 3). Likewise, sub-basins nos. 6 and 10 ranked third and fourth in the priorities, with $\mathrm{Cp}$ values of 26.1 and 26.7 respectively. By contrast, sub-basins nos. 15, 58 and 70 for example, are ranked as 47,46 , and 68 , with $C_{p}$ values 40.6 , 40.4, and 49.7 respectively, and with moderate priority. Further, sub-basins nos. $1,18,39$ are ranked as 72,73 , and with compound parameters at 51.7, 52.1, and 54.7 respectively (Table 3 ), and with moderate priority as well.

The W. Mujib-Wala watershed has been subjected to severe soil erosion over the last 3000 years, resulting in immense destruction of its vegetation cover. Supplementary information regarding current land use/cover, soil, slopes and topography were used as a guide in suggesting suitable soil and water conservation measures. The recommended measures were in accordance with priority ascribed in order to minimize negative impact of soil and land resources, rainfed farming, rangeland, and sedimentation in the Mujib and Wala dams. The expected advantages of expanding soil conservation measures, modernization of old soil conservation structures, enhancing farming practice, and rangeland management over sub-basins ranked as very high and high priority are manifested in the following: soil erosion loss control so as to protect soil from future erosion; minimizing sediment yield production to control sedimentation in the Mujib and Wala reservoirs; and reduced peak flow across the sub-watersheds and the entire W. Mujib-Wala catchment. Principal Component Analysis was used to reduce the original 16 basic and erosion risk morphometric parameters 
to three significant components which account $88 \%$ of the variance explained by the basic and erosion risk parameters. Out of ten parameters, six erosion risk variables were strongly correlated with $\mathrm{PC}_{1}$, and $\mathrm{PC}_{2}$ where both explained $46.2 \%$ of the total variance. One erosion risk parameter (circularity ratio) was highly correlated with $\mathrm{PC}_{1}$, and most of the erosion risk parameters exhibit loading values $>0.9$. The limitation of the morphometric analysis method of prioritization stated earlier was tested statistically using Discriminant Analysis. The results showed that the four priority classes significantly differ from each other; thus, prioritization based on the morphometric analysis approach is consistent, reliable, accepted, and of high capacity using RS and GIS technology. The present results are aimed so as to assist decision-makers in identifying priority sub-basins which need immediate adoption of appropriate conservation measures, and land management practices.

\section{References}

[1] Khresat, S.A., Al-Bakri, J. and Al-Tahhan, R. (2008) Impact of Land Use/Cover Change on Soil Properties in the Mediterranean Region of North Western Jordan. Land Degradation and Development, 19, 397-407. https://doi.org/10.1002/ldr.847

[2] Alkharabsheh, M., Alexandridis, K., Bilas, G., Misopolinos, N. and Silleos, N. (2013) Impact of Land Cover Change on Soil Erosion Hazard in Northern Jordan Using Remote Sensing and GIS. Procedia Environmental Sciences, 19, 912-921. https://doi.org/10.1016/j.proenv.2013.06.101

[3] Farhan, Y. and Nawaiseh, S. (2015) Spatial Assessment of Soil Erosion Risk Using RUSLE and GIS Techniques. Environmental Earth Sciences, 74, 4649-4669. https://doi.org/10.1007/s12665-015-4430-7

[4] Farhan, Y. (1986) Landslides in Central Jordan with Special Reference to the March 1983 Rainstorm. Singapore Journal of Tropical Geography, 7, 80-96. https://doi.org/10.1111/j.1467-9493.1986.tb00174.x

[5] Farhan, Y. (1999) Geomorphic Impacts of Highway Construction, their Causes and Remedies: A Case Study from Aqaba, Southern Jordan. Arab World Geographer, 5, 265-290.

[6] Farhan, Y. (2002) Slope Stability Problems in Central and Northern Jordan. Arab World Geographer, 5, 265-290.

[7] Farhan, Y., and Anaba, O. (2016a) Watershed Prioritization Based on Morphometric Analysis and Soil Loss Modeling in Wadi Kerak (Southern Jordan) Using GIS Techniques. International Journal of Plant and Soil Science, 10, 1-18. https://doi.org/10.9734/IJPSS/2016/25321

[8] Biswas, S., Sudhakar, S. and Desai, V. (1999) Prioritization of Sub-Watersheds Based on Morphometric Analysis of Drainage Basin: A Remote Rensing and GIS Approach. Journal of the Indian Society of Remote Sensing, 27, 155-166. https://doi.org/10.1007/BF02991569

[9] Thakkar, A.K. and Dhiman, S.D. (2007) Morphometric Analysis and Prioritization of Mini Watersheds in Mohr Watershed. Gujarat Using Remote Sensing and GIS Techniques. Journal of the Indian Society of Remote Sensing, 35, 313-321. https://doi.org/10.1007/BF02990787

[10] Patel, D.P., Gajjar, C.A. and Srivastava, P.K. (2013) Prioritization of Malesari 
Mini-Watersheds through Morphometric Analysis: A Remote Sensing and GIS Perspective. Environmental Earth Science, 69, 2643-2656. https://doi.org/10.1007/s12665-012-2086-0

[11] van Zuidam, R. and van Zuidam, C. (1979) Terrain Analysis and Classification Using Aerial Photographs: A Geomorphological Approach. ITC, Enschhede.

[12] Farhan, Y. and Anaba, O. (2016b) A Remote Sensing and GIS Approach for Prioritization of W. Shueib Mini-Watersheds (Central Jordan) Based on Morphometric and Soil Erosion Susceptibility Analysis. Journal of Geographic Information System, 8, 1-19. https://doi.org/10.4236/jgis.2016.81001

[13] Farhan, Y,, Anbar, A., Al-Shaikh, N. and Mousa, R. (2017) Prioritization of Semi-Arid Agricultural Watershed Using Morphometric and Principal Component Analysis, Remote Sensing, and GIS Techniques, the Zerqa River Watershed, Northern Jordan. Agricultural Sciences, 8, 113-148. https://doi.org/10.4236/as.2017.81009

[14] Al-Ansari, N. and Knutsson, S. (2012) Reduction of the Storage Capacity of Two Small Reservoirs in Jordan, Journal of Earth Science and Geotechnical Engineering, 2, 17-33.

[15] Al-Sherideh, M.S., Malkawi, A., Al-Hamdan, H. and Abdulrahman, N. (2000) Evaluating Sediment Yield at King Talal Reservoir from Landslides along Irbid-Amman Highway. Engineering Geology, 56, 361-372. https://doi.org/10.1016/S0013-7952(99)00119-2

[16] Ijam, A. and Al-Mahamid, M. (2012) Predicting Sedimentation at Mujib Dam Reservoir in Jordan. Jordan Journal of Civil Engineering, 6, 448-463.

[17] Ijam, A. and Tarawneh, E. (2012) Assessing of Sediment Yield for Wala Dam Catchment Area in Jordan. European Water, 38, 43-58.

[18] Mcdonald Partners and Hunting Technical Services LTD (1965) East Bank Water Resources Summary Report. Central Water Authority, Amman.

[19] Nearing, M.A., Ascough, L.D. and Laflen, J.M. (1990) Sensitivity Analysis of the WEPP Hillslope Profile Erosion Model. Transactions ASAE, 33, 839-849. https://doi.org/10.13031/2013.31409

[20] Irvem, A., Tapaloglu, F. and Uyagur, V. (2007) Estimating Spatial Distribution of Soil Loss over Seyhan River Basin in Turkey. Journal of Hydrology, 336, 30-37. https://doi.org/10.1016/j.jhydrol.2006.12.009

[21] Makwana, J. and Tiwari, M. (2016) Prioritization of Agricultural Sub-Watersheds in Semi Arid Middle Region of Gujarat Using Remote Sensing and GIS. Environmental Earth Sciences, 75, 1-12. https://doi.org/10.1007/s12665-015-4935-0

[22] Nooka Ratnam, K., Srivastava, Y.K., Venkateshwara Rao, V., Amminedu, E. and Murthy, K.S.R. (2005) Check Dam Positioning and Prioritization of Micro-Watersheds Using SYI Model and Morphometric Analysis-Remote Sensing and GIS Perspective. Journal of the Indian Society of Remote Sensing, 33, 25-38. https://doi.org/10.1007/BF02989988

[23] Khanday, M. and Javed, A. (2016) Prioritization of Sub-Watersheds for Conservation Measures in a Semi Arid Watershed Using Remote Sensing and GIS. Journal of the Geolojical Society of India, 88, 185-196. https://doi.org/10.1007/s12594-016-0477-7

[24] Gajbhiye, S. and Sharma, S.K. (2015) Prioritization of Watersheds through Morphometric Parameters: A PCA Approach. Applied Water Science, 7, 1505-1519.

[25] Patel, D.P., Dholakia, M., Naresh, N. and Srivastava, P.K. (2012) Water Harvesting 
Structure Positioning by Using Geo-Visualization Concept and Prioritization of Mini-Watersheds Through Morphometric Analysis in the Lower Tapi Basin. Journal of the Indian Society of Remote Sensing, 40, 299-312. https://doi.org/10.1007/s12524-011-0147-6

[26] Gajbhiye, S., Mishra, S.K. and Pandey, A. (2014) Prioritizing Erosion-Prone Area through Morphometric Analysis: An RS and GIS Perspective. Applied Water Science, 4, 51-61. https://doi.org/10.1007/s13201-013-0129-7

[27] Chandniha, S.L.K. and Kansal, M.L. (2017) Prioritization of Sub-Watersheds Based on Morphometric Analysis Using Geospatial Technology in Piperiya Watershed, India. Applied Water Science, 7, 329-338. https://doi.org/10.1007/s13201-014-0248-9

[28] Suresh, M., Sudhakar, S., Tiwari, K.N. and Chowdary, V.M. (2004) Prioritization of Watersheds Using Morphometric Parameters and Assessment of Surface Water Potential Using Remote Sensing. Journal of the Indian Society of Remote Sensing, 32, 249-259. https://doi.org/10.1007/BF03030885

[29] Hlaing, K.T., Haruyama, S. and Aye, M.M. (2008) Using GIS-Based Distributed Soil Loss Modeling and Morphometric Analysis to Prioritize Watersheds for Soil Conservation in Bago River Basin of Lower Myanmar. Frontiers of Earth Sciences in China, 2, 465-478. https://doi.org/10.1007/s11707-008-0048-3

[30] Fallah, M., Kavian, A. and Omidver, E. (2016) Watershed Prioritization in Order to Implement Soil and Water Conservation Practices. Environmental Earth Sciences, 75, 1248-1265. https://doi.org/10.1007/s12665-016-6035-1

[31] Spatarshi, P.G. and Raghavendara, R.K. (2009) GIS Based Evaluation of Micro-Watersheds to Ascertain Site Suitability for Water Conservation Structures. Journal of the Indian Society Remote Sensing, 37, 693-704. https://doi.org/10.1007/s12524-009-0057-z

[32] Javed, A., Khanday, M.A. and Ahmad, R. (2009) Prioritization of Sub-Watersheds Based on Morphometric and Land Use Analysis in Guna District (M.P.): A Remote Sensing and GIS Approach. Journal of the Indian Society of Remote Sensing, 37, 261-274. https://doi.org/10.1007/s12524-009-0016-8

[33] Javed, A., Khanday, M.A. and Rias, S. (2011) Watershed Prioritization Using Morphometric and Land Use/Land Cover Parameters: A Remote Sensing and GIS Approach. Journal of the Geological Society of India, 78, 63-75. https://doi.org/10.1007/s12594-011-0068-6

[34] Aher, P., Adinarayana, J. and Gorantwar, S. (2014) Quantification of Morphometric Characterization and Prioritization for Management Planning in Semi-Arid Tropics of India: A Remote Sensing and GIS Approach. Journal of Hydrology, 511, 850-860. https://doi.org/10.1016/j.jhydrol.2014.02.028

[35] Abdul Rahaman, S., Abul Ajeez, S., Aruchamy, S. and Jegankumar, R. (2015) Priotitization of Sub Watersheds Based on Morphometric Characteristics Using Fuzzy Analytical Hierarchy Process and Geographical Information System-A Study of Kallar Watershed, Tamil Nadu. Aquatic Procedia, 4, 1322-1330. https://doi.org/10.1016/j.aqpro.2015.02.172

[36] Singh, N. and Singh, K.K. (2017) Geomorphological Analysis and Prioritization of Sub-Watersheds Using Snyder's Unit Hydrograph Method. Applied Water Sciience, 6, 275-283. https://doi.org/10.1007/s13201-014-0243-1

[37] Burdon, D. (1959) Handbook of the Geology of Jordan. Benham and Co., Colchester. 
[38] De Jaegar, C. and de Dapper, M. (2002) Tectonic Control in the Geomorphic Development of Wadi el-Mujib Canyon (Jordan). EGU. Stephan Muller Special Publication Series, 2. 83-94. https://doi.org/10.5194/smsps-2-83-2002

[39] Farhan, Y. and Al-Shaikh, N. (2017) Quantitative Regionalization of W. Mujib-Wala Sub-Watersheds (Southern Jordan) Using GIS and Multivariate Statistical Techniques. Open Journal of Modern Hydrology, 7, 165-199. https://doi.org/10.4236/ojmh.2017.72010

[40] Al-Bakri, J. and Al-Jahmany, Y. (2013) Application of GIS and Remote Sensing to Groundwater Exploration in Al-Wala Basin in Jordan. Journal of Water Resources and Protection, 5, 962-971. https://doi.org/10.4236/jwarp.2013.510099

[41] Horton, R.E. (1945) Erosional Development of Streams and their Drainage Basins: Hydrological Approach to Quantitative Morphology. Geological Society of America Bulletin, 56, 275-370. https://doi.org/10.1130/0016-7606(1945)56[275:EDOSAT]2.0.CO;2

[42] Strahler, A.N. (1964) Quantitative Geomorphology of Drainage Basins and Channel Network. In: Chow, V.T., Ed., Handbook of Applied Hydrology, McGraw-Hill, New York, 4-76.

[43] Kanth, T. and Hassan, Z. (2012) Morphometric Analysis and Prioritization of Watersheds for Soil and Water Resources Management in Water Catchment Using Geo-Spatial Tools. International Journal of Geology, Earth and Environmental Sciences, 2, 30-41.

[44] Tuker, G.E. and Bras, R.L. (1998) Hillslope Processes, Drainage Density, and Landscape Morphology. Water Resources Research, 34, 2751-2764. https://doi.org/10.1029/98WR01474

[45] Schumm, S.A. (1956) Evolution of Drainage Systems and Slopes in Badlands at Perth Amboy, New Jersey. Geolical Society of America Bulletin, 67, 464-597. https://doi.org/10.1130/0016-7606(1956)67[597:EODSAS]2.0.CO;2

[46] Gravelius, H. (1914) Grundriß der Gesamten Gewässerkunde. Band 1:Flußkunde. Compendium of Hydrology, I, 265-278.

[47] Zavoianu, I. (1985) Morphometry of Drainage Basins (Developments in Water Science). Elsevier, Amsterdam.

[48] Miller, V. (1953) A Quantitative Geomorphic Study of Drainage Basin Characteristics in the Clinch Mountain Area, Virginia and Tennessee. Project NR 389-402, Technical Report 3, Columbia University, Department of Geology, ONR, New York.

[49] Strahler, A.N. (1957) Quantitative Analysis of Watershed Geomorphology. Transactions of the American Geophysical Union, 38, 913-920. https://doi.org/10.1029/TR038i006p00913

[50] Anderson, J., Hardy, E., Roach, J. and Witmer, R. (1976) A Land Use and Land Cover Classification System for Use with Remote Sensory Data. US Geological Survey Professional Paper 964, Washington DC.

[51] Ministry of Agriculture, Jordan (1995) The Soils of Jordan. Report of the National Soil Map and Land Use Project. Ministry of Agriculture, Hunting Technical Services LTd. and European Commission, Amman.

[52] Al-Saady, Y., Al-Suhail, Q., Al-Tawash, B. and Othman, A. (2016) Drainage Network Extraction and Morphometric Analysis Using Remote Sensing and GIS Mapping Techniques (Lesser Zab River Basin, Iraq and Iran). Environmental Earth Sciences, 66, 537-548. 
[53] Chorley, R., Donald, M. and Pogorzelski, H. (1957) A New Standard for Estimating Drainage Basin Shape. American Journal Science, 255, 138-141. https://doi.org/10.2475/ajs.255.2.138

[54] Farhan, Y. and Ayed, A. (2017) Assessment of Flash-Flood Hazard in Arid Watersheds of Jordan. Journal of Geographic Information System, 9, 717-751. https://doi.org/10.4236/jgis.2017.96045

[55] Farhan, Y. (2017) Morphometric Assessment of Wadi Wala Watershed, Southern Jordan Using ASTER (DEM) and GIS. Journal of Geographic Information System, 9, 158-190. https://doi.org/10.4236/jgis.2017.92011

[56] Cordova, C.E. (2000) Geomorphological Evidence of Intense Prehistoric Soil Erosion in the Highlands of Central Jordan. Physical Geography, 21, 538-567.

[57] Shammout, S. (1980) The Jordanian Experience in Rainfed Agriculture. Paper Submitted to the Rainfed Agriculture in the Near East and North Africa Meeting, FAO, Rome.

[58] Abu-Zreig, M.M., Tamimi, A. and Alazba, A.A. (2011) Soil Erosion Control and Moisture Conservation in Arid Lands with Stone Cover. Arid Land Research and Management, 25, 294-307. https://doi.org/10.1080/15324982.2011.565859

[59] Sharaiha, R. and Ziadat, F. (2007) Alternative Cropping Systems to Control Soil Erosion in Arid to Semi-Arid Areas of Jordan. African Crop Science Conference Proceedings, 8, 1559-1565.

[60] Mather, P.M. and Doornkamp, J.C. (1970) Multivariate Analysis in Geography. Transactions of the Institute of British Geographers, 51, 163-187.

https://doi.org/10.2307/621768 